NBER WORKING PAPER SERIES

THE COST OF FUEL ECONOMY IN THE INDIAN PASSENGER VEHICLE MARKET

\author{
Randy Chugh \\ Maureen L. Cropper \\ Urvashi Narain \\ Working Paper 16987 \\ http://www.nber.org/papers/w16987
NATIONAL BUREAU OF ECONOMIC RESEARCH
1050 Massachusetts Avenue
Cambridge, MA 02138
April 2011

\begin{abstract}
We thank Mark Jacobson, Rob Williams, and Hendrik Wolff for helpful suggestions and John Allen Rogers for many useful discussions and assistance in obtaining data. We also thank seminar participants at University of Maryland, College Park; the 2009 Western Economic Association International conference in Vancouver, British Columbia; and the 2010 Allied Social Sciences Association meetings in Atlanta, Georgia. This paper was funded by the World Bank's KCP Trust Fund. The findings and conclusions of this paper are those of the authors and do not necessarily represent the views of the World Bank, its affiliated organizations, the Executive Directors of the World Bank, the governments they represent, or the National Bureau of Economic Research.
\end{abstract}

NBER working papers are circulated for discussion and comment purposes. They have not been peerreviewed or been subject to the review by the NBER Board of Directors that accompanies official NBER publications.

(C) 2011 by Randy Chugh, Maureen L. Cropper, and Urvashi Narain. All rights reserved. Short sections of text, not to exceed two paragraphs, may be quoted without explicit permission provided that full credit, including $\odot$ notice, is given to the source. 
The Cost of Fuel Economy in the Indian Passenger Vehicle Market

Randy Chugh, Maureen L. Cropper, and Urvashi Narain

NBER Working Paper No. 16987

April 2011

JEL No. L62,Q4

\begin{abstract}
$\underline{\text { ABSTRACT }}$
To investigate how fuel economy is valued in the Indian car market, we compute the cost to Indian consumers of purchasing a more fuel-efficient vehicle and compare it to the benefit of lower fuel costs over the life of the vehicle. We use hedonic price functions for four market segments (petrol hatchbacks, diesel hatchbacks, petrol sedans, and diesel sedans) to compute 95 percent confidence intervals for the marginal cost to the consumer of an increase in fuel economy. We find that the associated present value of fuel savings falls within the 95 percent confidence interval for some specifications, in all market segments, for the years 2002 through 2006. Thus, we fail to consistently reject the hypothesis that consumers appropriately value fuel economy. When we reject the null hypothesis, the marginal cost of additional fuel economy exceeds the present value of fuel savings, suggesting that consumers may, in fact, be overvaluing fuel economy.
\end{abstract}

Randy Chugh

Department of Economics

University of Maryland

College Park, MD 20742

chugh@econ.umd.edu

Maureen L. Cropper

Department of Economics

University of Maryland

College Park, MD 20742

and NBER

cropper@econ.umd.edu
Urvashi Narain

Environment Department

World Bank

Washington, DC 20433

unarain@worldbank.org 


\title{
The Cost of Fuel Economy in the Indian Passenger Vehicle Market
}

\author{
Randy Chugh, Maureen Cropper, and Urvashi Narain*
}

\section{Introduction}

As a result of India's economic boom, the demand for passenger vehicles has grown swiftly over the last decade. In April 2002, passenger vehicle sales were approximately 50,000; by April 2008, monthly sales had tripled to approximately $150,000 .{ }^{1}$ With such rapid growth, many in India are advocating for strong legislative action to avoid the many economic, security, and environmental concerns that may accompany the expansion of the vehicle fleet.

As fuel consumption is of concern for both energy security and environmental reasons, much of the Indian debate has centered on policies to increase vehicle fuel economy. One argument for fuel economy standards (as opposed to higher fuel taxes) is that consumers undervalue fuel savings; that is, they fail to buy a more fuel-efficient vehicle even though the additional purchase price is less than the present value of fuel savings. This hypothesis has been tested extensively in the United States. Although much of the literature suggests that consumers undervalue fuel savings (Allcott and Wozny 2010), other studies (Sallee et al. 2010) suggest that consumers are willing to pay an extra dollar when buying a car to reduce the present value of fuel costs by a dollar. This paper examines how car buyers in India value fuel savings.

The approaches that have been used in the United States to determine whether consumers undervalue fuel economy include hedonic price methods, studies of the impact of gasoline prices on used car prices, and structural estimates of the parameters of consumers' utility functions (Greene 2010; Helfand and Wolverton 2010). Hedonic price methods compare what consumers must pay for additional fuel economy in the market — as estimated by a hedonic price locus-

\footnotetext{
* Chugh, Department of Economicsm University of Maryland, College Park, chugh@econ.umd.edu; Cropper, Department of Economics, University of Maryland, College Park, and Resources for the Future, cropper@rff.org; Narain, World Bank, unarain@worldbank.org. We thank Mark Jacobson, Rob Williams, and Hendrik Wolff for helpful suggestions and John Allen Rogers for many useful discussions and assistance in obtaining data. We also thank seminar participants at University of Maryland, College Park; the 2009 Western Economic Association International conference in Vancouver, British Columbia; and the 2010 Allied Social Sciences Association meetings in Atlanta, Georgia. This paper was funded by the World Bank's KCP Trust Fund. The findings and conclusions of this paper are those of the authors and do not necessarily represent the views of the World Bank and its affiliated organizations, the Executive Directors of the World Bank, or the governments they represent.

${ }^{1}$ To put these figures in perspective, January 2008 monthly sales were approximately 1 million in the United States and approximately 650,000 in China.
} 
with the associated reduction in fuel expenditures (Espey and Nair 2005). ${ }^{2}$ If the two are equal, when evaluated at chosen vehicle bundles, the null hypothesis that consumers rationally value fuel economy cannot be rejected. The advantage of this approach is that it does not require data on market shares; however, because estimates often rely on cross-sectional variation in vehicle characteristics, multicollinearity can make it difficult to obtain precise estimates of the marginal price of fuel economy, and omitted variable bias is a concern.

The hypothesis that consumers accurately value fuel economy has also been tested using data on used car prices. Because the used car market is competitive, the prices of used cars should adjust to reflect changes in the price of gasoline (Li et al. 2009). ${ }^{3}$ Indeed, if consumers correctly value fuel economy, prices should adjust fully to reflect the change in the present value of fuel expenditures (Sallee et al. 2010). This can be tested by examining variation in car and gasoline prices while holding vehicle characteristics fixed.

A third approach, used by Allcott and Wozny (2010), is to examine how consumers trade off the present value of fuel expenditures against purchase price, holding other vehicle characteristics constant. This requires identifying the parameters of consumers' utility functions. Recognizing that both the demand and supply of new vehicles respond to gasoline prices, Allcott and Wozny use expected vehicle operating cost at the time when the vehicle was new to instrument for the quantity of used vehicles available on the market.

Unfortunately, approaches that have been used in the United States to examine how consumers value fuel economy are difficult to apply in India because of a lack of data (e.g., on used car prices) and insufficient variation in the price of fuel over time. In this paper, we take a simpler hedonic price approach to examine how Indian car buyers value fuel economy.

\subsection{Our Approach}

We test the hypothesis that consumers accurately value fuel economy by computing the marginal price that consumers face for an improvement in fuel economy and comparing this to the present value of associated fuel savings. For each of four vehicle types (petrol hatchbacks, diesel hatchbacks, petrol sedans, and diesel sedans), we estimate hedonic price functions treating

\footnotetext{
${ }^{2}$ In an oligopolistic car market, the hedonic price function represents the locus of opportunities facing car buyers, even though it is no longer the envelope of tangencies between marginal bid and marginal offer curves.

${ }^{3}$ Klier and Linn (2009) use a similar approach in the new car market. They examine whether, within a given model year, monthly variation in gasoline prices is reflected in new car prices and market shares.
} 
fuel economy as one of several performance characteristics. To account for the possible correlation between fuel economy and unobserved vehicle characteristics, we instrument for the fuel economy of, for example, petrol hatchbacks of a given make using the average fuel economy of petrol sedans of the same make. We use these estimates to compute a 95 percent confidence interval for the marginal price of fuel economy and ask whether the present value of fuel savings falls within this interval.

Based on these results, we cannot reject the null hypothesis that the mean consumer equates the marginal price of fuel economy to the present value of fuel savings in the markets for petrol hatchbacks or petrol sedans. In the markets for diesel hatchbacks and diesel sedans, however, we reject the null hypothesis for at least some specifications in all years. In these markets, we find evidence that consumers are paying more for fuel economy than the present value of fuel savings.

We also examine the trade-offs faced by buyers of twins, models that are available in both petrol and diesel form. Diesel versions are generally more expensive than their petrol twins, but cost less to operate because of their greater fuel economy and the fact that diesel fuel is 30 percent cheaper than petrol. The savings that buyers of diesel twins realize over the life of their vehicles are substantial. Averaged over available models for the years 2002 to 2008, diesel hatchback owners save the equivalent of 44 percent of the purchase price of their chosen vehicle by selecting it over its petrol twin; diesel sedan owners save 23 percent. The percentage of twin hatchback owners taking advantage of these savings by buying the diesel twin has risen each year from 46 percent in 2002 to 74 percent in 2006. Similarly, 17 percent of twin sedan owners bought the diesel twin in 2002, and this rose to 59 percent in 2006.

Does this mean that buyers of petrol twins undervalue fuel economy? Petrol car buyers drive fewer kilometers than buyers of diesel cars, but the fuel savings from buying a diesel twin still outweigh the additional purchase price. Petrol hatchback owners could have saved 23 percent of the purchase price of their chosen vehicle by buying a diesel; petrol sedan owners could have saved 15 percent. Diesel cars, however, differ from their petrol twins in other performance characteristics: they are generally heavier and less powerful. It is possible that petrol car buyers accurately value fuel economy but are willing to forgo potential savings to buy a more powerful car. In fact, the fuel savings forgone are a lower bound to the value rational petrol car buyers place on these differences in characteristics as the savings they give up by buying the petrol twin. 
The rest of the paper is organized as follows. Section 2 presents stylized facts about the Indian vehicle market. Section 3 presents our hedonic analysis, and Section 4 compares the cost and fuel economy of petrol and diesel twins. Section 5 concludes.

\section{Overview of the Indian Passenger Vehicle Market}

Sales of passenger vehicles in India have been growing rapidly - from approximately 50,000 cars per month in 2002 to approximately 150,000 per month in 2008 . The market is highly concentrated, with the top five manufacturers accounting for nearly 90 percent of the market between 2002 and 2006. Maruti Suzuki accounted for 48 percent of sales, Tata Motors 18 percent, and Hyundai 15 percent. Mahindra and Toyota each accounted for 4 percent. Figure 1 shows average market shares by body type and fuel type for the same period. The majority of passenger vehicles sold in India are small cars: hatchbacks constitute approximately 65 percent of the market, sedans about 17 percent, sport utility vehicles (SUVs) 12 percent, and vans 5 percent. ${ }^{4}$

Averaged over the years 2002 through 2006, 73 percent of passenger vehicles ran on petrol and 27 percent on diesel, but the fuel breakdown varied significantly by body type. Approximately 85 percent of hatchbacks and 75 percent of sedans ran on petrol, whereas virtually all SUVs ran on diesel (only 3 percent used petrol). Because we examine the petrol/diesel fuel choice, the remainder of the paper focuses on hatchbacks and sedans. Figures 2 and 3 demonstrate the changing petrol and diesel composition of new vehicle sales. For hatchbacks, diesel market share has remained constant at around 15 percent between 2002 and 2006. For sedans, a clear trend of increasing diesel market share (i.e., dieselization) has taken place, from 11 percent in 2002 to 32 percent in 2006.

Fuel prices are set by the Indian government and vary little across cities. ${ }^{5}$ In our analysis, we use fuel prices in Delhi, which are pictured in Figure 4. An unfortunate feature of Figure 4from the perspective of an econometrician - is the lack of variation in fuel prices. Between 2005 and 2008, gasoline prices in the United States doubled. This provided a natural experiment that enabled economists to examine how the used car market reacted to changes in the value of fuel economy (Klier and Linn 2009; Li et al. 2009; Sallee et al. 2010). In India, fuel prices remained almost flat. The gap between petrol and diesel prices does, however, provide variation in the

\footnotetext{
4 The remainder of the market is composed of multi-use vehicles (MUVs), wagons, and coupes.

5 The January 2006 price of petrol (in 2008 Rs. per liter) was 54.3 in Mumbai, 51.8 in Calcutta, and 48.1 in Delhi.
} 
value of fuel economy between fuel types. As Figure 4 illustrates, diesel fuel is about 30 percent cheaper than petrol, with petrol selling at 48 Rs. per liter ( $\$ 4.60$ per gallon) and diesel at 34 Rs. per liter (\$3.20 per gallon) in $2006 .^{6}$

Tables 1 and 2 describe the characteristics of petrol and diesel hatchbacks and sedans. Table 1 describes vehicle characteristics at the model level for the period 2002 to 2006, weighted by market share. Table 2 summarizes vehicle characteristics at the version level, not weighted by market share, for the period 2002 through $2008 .{ }^{7}$ Vehicle characteristics data, which cover the period 2002 to 2008, come from AutoCar India and other sources. Data on market share and average distance driven each month by the buyers of each model come from the J.D. Power Automotive Performance, Execution, and Layout (APEAL) Survey and are available for the years 2002 to $2006 .^{8}$

How do diesel and petrol cars compare in terms of fuel economy and other performance characteristics? Diesel hatchbacks are heavier and less powerful than petrol hatchbacks (see Table 1) but have better fuel economy in city driving. ${ }^{9}$ The fact that diesel hatchbacks weigh more reflects their larger engine size: no diesel hatchbacks are produced with engines smaller than 1,250 cubic centimeters, which is larger than the mean petrol hatchback engine. On average, diesel hatchbacks have more torque than petrol hatchbacks, but their ratio of torque to weight is lower. Diesel hatchbacks have about 1 kilometer-per-liter $(\mathrm{kpl})$ greater fuel economy than petrol hatchbacks (sales weighted). The difference in fuel economy is much greater between diesel and petrol sedans: diesel sedans have about $2.7 \mathrm{kpl}$ greater fuel economy than petrol sedans. Diesel

\footnotetext{
${ }^{6}$ Diesel fuel in India is priced below petrol because of its uses in the agricultural sector. The gap between the two fuel prices has remained constant in percentage terms since around 2002, but the historic percentage gap is even greater.

${ }^{7}$ The vehicle characteristics in Table 1 are the same as those in Table 2, but have been aggregated to the model level and then weighted by market share. Because our market share data cover the period 2002 to 2006, all averages in Table 1 pertain to that period.

${ }^{8}$ Vehicle price and characteristics data come from AutoCar India, an Indian car industry magazine, and Segment Y, a private market research firm. Additional data on body type classification and fuel type come from Carwale, a website that provides information for car buyers (www.Carwale.com). All market share data come from the 20022006 waves of the J.D. Power Asia Pacific's APEAL study, an annual survey of more than 5,500 new car buyers in India.

${ }^{9}$ We use city fuel economy rather than highway fuel economy throughout the paper. Data on fuel economy reported by respondents in the APEAL survey correlate much better with city fuel economy than highway fuel economy, as reported in AutoCar India. A regression through the origin of buyers' estimates of fuel economy on published estimates of city fuel economy yields a coefficient of 0.83 (s.e. $=0.0087$ ); when highway fuel economy is added to the equation, the coefficient on city fuel economy equals $1.00($ s.e. $=0.10)$ and the coefficient on highway fuel economy is 0.12 (s.e. $=0.078)$.
} 
sedans have a horsepower-to-weight ratio that is only 70 percent of that of a petrol sedan, but have 15 percent more torque and a 5 percent higher torque-to-weight ratio.

To put our study in perspective, we note that Indian cars are lighter and less powerful than cars in the United States (U.S. Environmental Protection Agency [EPA] 2008). Between 2002 and 2006, the average weight of an Indian petrol hatchback (sales weighted) was about 1,700 pounds; for an Indian petrol sedan it was 2,200 pounds. In the United States in 2006, the average car weighed approximately 3,500 pounds. ${ }^{10}$ The average horsepower-to-weight ratio (in horsepower per pound) was 0.032 for the Indian petrol hatchback, 0.041 for the Indian petrol sedan, and 0.054 for an average car in the United States. In view of their lighter weight and lower horsepower ratio, it is not surprising that the average fuel economy of the Indian petrol hatchback and sedan (28.3 and 22.3 miles per gallon in city driving, respectively) was greater than that of the average U.S. car (19.4 miles per gallon). ${ }^{11}$ Estimates of fuel economy technical frontiers, which show how fuel economy varies with vehicle characteristics, suggest that Indian cars are not necessarily as fuel efficient as U.S. cars, holding weight and horsepower constant. ${ }^{12}$

\section{Hedonic Price Approach}

The hedonic approach to evaluating how buyers value fuel economy asks whether consumers equate the marginal cost of buying a more fuel-efficient vehicle to the present value of fuel savings. Such a comparison tests the null hypothesis that new car buyers are willing to pay an extra rupee in purchase price to decrease the present value of fuel costs by a rupee. Formally, new car buyers face a function that describes vehicle price $(P)$ as a function of fuel economy $(\mathrm{kpl})$ and other vehicle characteristics $(Z)$, such as weight, horsepower, and type of transmission (automatic or manual). We assume quasilinear preferences over consumption of an outside good $(x)$ and vehicle subutility $(\mathrm{u})$, which depends on $\mathrm{Z}$ and monthly driving distance $(K)$, but not directly on fuel economy. Each buyer chooses the $(Z, K, k p l)$ bundle that maximizes his utility $(U)$

$$
U=x+u(Z, K)
$$

\footnotetext{
10 The EPA car category is comparable to our hatchbacks and sedans, as it excludes SUVs, wagons, vans, and pickup trucks.

11 The figures for the United States are the adjusted city miles per gallon as reported in EPA (2008, Table 1), rather than laboratory results.

12 When a fuel economy technical frontier model estimated using Indian data is used to predict the fuel economy of an average U.S. car, predicted fuel economy is less than 16 miles per gallon (Chugh et al. 2010).
} 
If the buyer is sufficiently forward looking, he considers the impact of $\mathrm{kpl}$ on the present value of fuel costs over the life of the vehicle, and thus faces the budget constraint

$$
y=x+P(k p l, Z)+K \sum_{t=0}^{T} \frac{1}{(1+r)^{t}} \frac{p_{f}(t)}{k p l} .
$$

In equation (2), $y$ is wealth, $T$ is the life of the vehicle, $r$ is the buyer's discount rate, and $p_{f}(t)$ the (expected) price of fuel in year $t$. The first-order conditions for this problem imply that, at the chosen level of fuel economy, the marginal cost of an additional unit of fuel economy must equal the resulting reduction in fuel costs

$$
\frac{\partial P}{\partial k p l}=K \sum_{t=0}^{T} \frac{1}{(1+r)^{t}} \frac{p_{f}(t)}{k p l^{2}} .
$$

To test whether this condition is satisfied, we estimate hedonic price functions facing consumers in four vehicle markets - petrol hatchbacks, diesel hatchbacks, petrol sedans, and diesel sedans - and compute the 95 percent confidence intervals for the cost of a $1 \mathrm{kpl}$ increase in fuel economy, evaluated at the sales-weighted mean $(Z, k p l)$ vector for each vehicle type. We compute the associated reduction in fuel costs over the life of the vehicle using the salesweighted mean monthly driving distance in each market.

Because we focus on sales-weighted mean vehicle characteristics and driving distance, ours is a test of whether car buyers choose fuel economy optimally, on average. Note also that equation (2) treats the new car buyer as the sole owner of the vehicle. Our null hypothesis thus assumes that both the new and used car markets operate efficiently. An alternative would be to evaluate the rationality of new car buyers, conditional on prices in the used car market. Data on the used car market in India are, however, not readily available.

\subsection{Estimation of the Hedonic Price Function}

The problems involved in estimating the marginal price of fuel economy using hedonic price functions are well known. Correlation between fuel economy and vehicle characteristics, such as weight and horsepower, make precise estimation of the marginal price difficult, and omitted variable bias may render estimates inconsistent (Atkinson and Halvorsen 1984; Espey 
and Nair 2005). To deal with these issues, we instrument for fuel economy and use a flexible, semilog specification and alternate sets of vehicle characteristics to demonstrate robustness to specification. For comparison purposes, we also present ordinary least squares (OLS) results.

We estimate the log of vehicle price as a function of subsets of vehicle characteristics described in Table 3

$$
\log P\left(Z_{j}\right)=\sum_{i=1}^{n} \beta_{i} z_{i}+\gamma_{i} z_{i j}^{2}+\epsilon_{j}
$$

For ease of interpretation, we present results that are based on the linear $\left(\gamma_{i}=0\right)$ version of equation (4); additional results are presented in the appendix. ${ }^{13}$

The vehicle characteristics that are most highly correlated with fuel economy, but which are valued in their own right, are vehicle weight and engine performance. Engine performance is usually measured by torque (or horsepower) and by engine size. ${ }^{14}$ Horsepower (or torque) relative to vehicle weight determines how much "pickup" a car has (e.g., how well it accelerates). We use a combination of engine size, torque, and the ratio of horsepower to weight to measure performance. We also control for a vehicle's luxury and safety features and whether it has an automatic transmission. The data used to estimate hedonic price functions (summarized in Table 2) include all versions available in each market over the period 2002-2008, unweighted by sales.

We separate the market into sedans and hatchbacks as vehicles of very different sizes and price ranges are unlikely to be close substitutes. We also segment the market according to fuel type as the marginal price of fuel economy is likely to differ by fuel type as a result of the dieselpetrol price differential. Wald tests allow us to reject the null hypothesis that these market segments should be combined.

We instrument for fuel economy because gains in fuel economy are often achieved by sacrifices in weight, horsepower, and other desirable characteristics. Although we control for observable characteristics in our model, failure to account for correlation between higher fuel

\footnotetext{
13 Results are robust to the inclusion of higher-order terms for all vehicle categories except petrol sedans. For these vehicles, use of our instrument means that instrumental variable (IV) estimates are based on only 216 observations compared to 411 for OLS. OLS results, however, are robust to the inclusion of higher-order terms for all vehicle categories.

${ }^{14}$ Holding engine speed constant, horsepower is a multiple of torque.
} 
economy and unobservable attributes may bias our fuel economy coefficients downward. We instrument for the fuel economy of petrol hatchbacks of a given make using the average fuel economy of petrol sedans of the same make. We instrument for the fuel economy for each petrol sedan of a given make using the average fuel economy of petrol hatchbacks of the same make. Instruments for diesel vehicles are constructed analogously. ${ }^{15}$ Our instrument reflects the fuel economy technology available to manufacturers at the time of vehicle design. Sedan fuel economy should be correlated with hatchback fuel economy, but not with unmeasured hatchback design characteristics, provided manufacturers' design decisions are made separately for each vehicle segment.

\subsection{Hedonic Price Function Results}

Instrumental variable (IV) estimates of hedonic price functions for each market segment are presented in Tables $4-7 .{ }^{16}$ The models fit well $\left(\mathrm{R}^{2}\right.$ values range from 0.781 to 0.947$)$, and most coefficients are statistically significant, with expected signs. Vehicle price varies positively with weight, horsepower-to-weight ratio, torque, engine size, luxury index, and automatic transmission (relative to manual). For all vehicle categories, quality-adjusted prices are approximately 20-40 percent lower in 2008 than in 2002 . Holding vehicle characteristics constant, petrol car prices have fallen more than diesel car prices.

What is the marginal cost to consumers of buying a car with greater fuel economy? Table 8 summarizes the coefficients of fuel economy from Tables 4-7 and contrasts them with the corresponding OLS estimates. (OLS models corresponding to Tables 4-7 are presented in Appendix Tables A.1-A.4.) IV estimates from Table 8 suggest that the cost of fuel economy ranges from 3 to 10 percent of vehicle price. As expected, this is higher than the marginal cost in the OLS models, suggesting that fuel economy is negatively correlated with desirable, but

\footnotetext{
15 Thus, the 2002 Fiat petrol hatchbacks, the Palio (which comes in 11 versions) and the Uno (which comes in 2 versions), all have the same value of the instrument, which is constructed as the average fuel economy of all 7 versions of the 2002 Fiat petrol sedan (the Siena). The 2002 Fiat Sienas (all 7 versions) share the same IV value, which is equal to the average fuel economy of all 132002 Fiat petrol hatchbacks.

${ }^{16}$ We do not present first-stage results for our IV estimates; however, the coefficient on our instrument is significantly different from zero at the 0.025 level or better in all models.
} 
unmeasured, vehicle characteristics. The marginal price of fuel economy is, in general, robust to the inclusion of squared terms in the hedonic price function, as shown in Appendix Table A.5.17

Because the fuel economy coefficient in each market varies with equation specification, we compute 95 percent confidence intervals for a $1 \mathrm{kpl}$ increase in fuel economy for a variety of specifications. We compute confidence intervals holding all other vehicle characteristics at their sales-weighted means for each year. Table 9 illustrates the cost of a $1 \mathrm{kpl}$ increase in fuel economy for the years 2002-2006 for each market segment based on the first model in Tables 47. The marginal price of fuel economy is falling in each market between 2002 and 2005 . This reflects the fact that, holding vehicle characteristics constant, the real price of a car is falling in each market over this period.

\subsection{The Savings from Improved Fuel Economy}

We compute the savings from a $1 \mathrm{kpl}$ increase in fuel economy using the discrete counterpart to equation (3)

$$
K \sum_{t=0}^{T} \frac{1}{(1+r)^{t}}\left(\frac{p(t)}{k p l}-\frac{p(t)}{k p l+1}\right)
$$

Savings are evaluated in each market segment based on the mean monthly driving distance by buyers in that segment, averaged over the years 2002 through 2006. These monthly driving distances are 1,070 kilometers (petrol hatchback owners), 1,870 kilometers (diesel hatchback owners), 1,300 kilometers (petrol sedan owners), and 1,870 kilometers (diesel sedan owners). Drivers of diesel cars drive more than drivers of petrol cars and therefore save more from a given fuel economy improvement.

To calculate fuel savings, we must also make assumptions about vehicle life, interest rates, and future fuel prices. In 2007, the median life of a car in the United States was 9.2 years (Bureau of Transportation Statistics 2008). Cars are held for longer periods in most developing countries, but data on vehicle life in India are scarce. Rogers (2009) suggests that median vehicle life for new cars in India is about 11 years for hatchbacks and 12 years for sedans. Interest rates are also higher in India than in the United States. To illustrate this, consider the official (real)

\footnotetext{
17 The one exception to this is the market for petrol sedans. The coefficients of fuel economy in our OLS models, based on 411 observations, are robust to the inclusion of squared terms. However, when the OLS models are estimated using the sample available for IV estimation (216 observations), the results are no longer robust. This is also true for the IV models when squared terms are included.
} 
interest rate used by the government of India, which is 12 percent, compared to 7 percent in the United States. We use a discount rate of 15 percent for car buyers, based on interest rates charged on new car loans in India (Shankar 2007; Carazoo n.d.; Seth 2009). Following Anderson et al. (2010), we assume that consumers expect future fuel prices to follow a random walk. This allows us to replace $p_{f}(t)$ in equation (2) with $p_{f}(0)$, the price of fuel at the time of vehicle purchase. ${ }^{18}$

Table 9 presents point estimates of the present value of fuel savings associated with a 1 $\mathrm{kpl}$ increase in fuel economy (measured from its mean value) in each market. To put these numbers in perspective, we also show the present value of fuel expenditures for each vehicle class (evaluated at mean monthly driving distance) and the percentage decrease in these expenditures from a $1 \mathrm{kpl}$ increase in fuel economy. In 2006, for diesel hatchbacks and sedans and petrol hatchbacks, a $1 \mathrm{kpl}$ increase in fuel economy lowers lifetime fuel expenditures by about 7.5 percent; for petrol sedans, it lowers expenditures by about 9.5 percent. Fuel savings are increasing in absolute terms over the 2002 to 2006 period as a result of increases in the real prices of both diesel and petrol.

\subsection{Comparison of the Marginal Price of Fuel Economy and Fuel Savings}

To test the null hypothesis that consumers equate the marginal price of fuel economy to the present value of fuel savings, we subtract the fuel savings reported in Table 9 from the marginal price of fuel economy to construct 95 percent confidence intervals of the net costs of purchasing additional fuel economy. We do this for all models in Tables 4-7. If zero lies within this interval, we cannot reject the null hypothesis. The tests of our null hypothesis, illustrated in Figures 5-8, suggest that Indian consumers do not undervalue fuel economy. In the markets for petrol hatchbacks and petrol sedans, we cannot reject the null hypothesis that the marginal cost of fuel economy is equated to the present value of fuel savings for any model specification in any year. In the markets for diesel hatchbacks and diesel sedans, we can reject the null hypothesis for some models and years; however, in all cases in which the null hypothesis is rejected, the net cost of fuel economy is positive, implying that consumers are buying too much fuel economy. Our results thus provide little support for the argument that fuel economy standards in India are justified because consumers undervalue fuel economy.

\footnotetext{
${ }^{18}$ For each model year, we construct a sales-weighted average petrol price and a sales-weighted average diesel price. We weight monthly fuel price by monthly vehicle sales, reported in Indiastat.com.
} 


\section{Lowering Fuel Costs by Purchasing a Diesel Vehicle}

Another way in which consumers can reduce their fuel costs is to purchase a diesel car rather than a petrol one. Diesel cars are more fuel efficient, and diesel fuel is about 30 percent cheaper per liter than petrol. In this section, we compare the additional cost of buying a diesel vehicle with the savings in fuel costs using data on twins - models that are available in both diesel and petrol form. More sedans than hatchbacks are available in diesel form. Of the 34 petrol sedan models available in 2006, 12 of them had diesel twins, whereas only 2 of 11 petrol hatchback models available in 2006 had a diesel twin. A similar pattern is reflected in market shares: in 2002, twins accounted for 62 percent of sedan sales and 31 percent of hatchback sales. In 2006, twins accounted for 54 percent of sedan and 19 percent of hatchback sales.

On average, diesel twins cost more, but have better fuel economy. Table 10 shows regressions of the log of price and the log of fuel economy on a diesel dummy variable and model-year dummy variables for the hatchback and sedan markets. On average, diesel hatchbacks cost 9.4 percent more than their petrol twins; diesel sedans cost 7.7 percent more. The difference in fuel economy is large: diesel hatchbacks are on average 27 percent, and diesel sedans 30 percent, more fuel efficient than their petrol twins. On average, a diesel car travels 3 kilometers farther on a liter of fuel than its petrol twin.

\subsection{The Cost Savings from Buying a Diesel Twin}

The cost advantage of a diesel twin is the difference between the purchase price of the petrol and diesel versions of the vehicle plus the present value of savings in fuel costs over the life of the vehicle

$$
P_{p}-P_{d}+K \sum_{t=0}^{T} \frac{1}{(1+r)^{t}}\left(\frac{p_{p}(t)}{k p l_{p}}-\frac{p_{d}(t)}{k p l_{d}}\right)
$$

where the $p$ and $d$ subscripts refer to petrol and diesel, respectively.

The fuel savings of a diesel are substantial: the fuel cost per kilometer of a diesel car is about half that of its petrol twin. To illustrate, a petrol sedan that achieves average fuel economy $(9 \mathrm{kpl})$ costs 5Rs. per kilometer to operate at a petrol price of 45 Rs. per liter (roughly the current price). Its diesel twin, with a fuel economy of $12 \mathrm{kpl}$, costs only $2.5 \mathrm{Rs}$. per kilometer because diesel fuel is one-third cheaper (30 Rs. per liter). The corresponding figures for hatchbacks are 
4.5 Rs. per kilometer for petrol hatchbacks vs. 2.3 Rs. per kilometer for their petrol twins. ${ }^{19}$ In both cases, two-thirds of the reduction in fuel costs is due to the lower price of diesel and onethird to the better fuel economy of diesel vehicles. ${ }^{20}$

Total fuel savings from buying the diesel twin increase with driving distance. For buyers who drive 2,000 kilometers per month, the present value of fuel savings is about 171,000 Rs. over the life of a hatchback and 334,000 Rs. over the life of a sedan. For buyers who drive 1,000 kilometers per month, the savings are still substantial: about 85,500 Rs. for a hatchback and 167,000 for a sedan. To obtain net savings, the difference in purchase price of the diesel and petrol vehicles (42,500 Rs. for hatchbacks and 86,600 Rs. for sedans) must be subtracted from the fuel savings.

The average figures in the previous paragraph mask heterogeneity across models in the net fuel savings from buying a diesel. Figures 9 and 10 plot the net fuel savings from buying a diesel for 21 hatchback and 70 sedan models for which a twin was available over the period 2002-2006. In these computations, fuel savings are based on mean monthly driving distances for each vehicle type. In both figures, the savings from buying a diesel vehicle are expressed as a percentage of the price of its petrol twin.

The distribution of forgone savings for persons who bought a petrol car lies to the left of the distribution of savings realized by diesel car buyers in both figures. This is not surprising as petrol car buyers drive fewer kilometers per year than diesel buyers and therefore enjoy smaller fuel savings. On average, the fuel savings realized by buyers of diesel hatchbacks were 48 percent of the price of a petrol hatchback; the corresponding figure for diesel sedan owners was 25 percent. At the same time, buyers of petrol hatchbacks gave up savings equal to 23 percent of the price of their cars, and buyers of petrol sedans gave up savings equal to 15 percent of the price of their cars.

The important question is: what percentage of twin buyers realized these savings? In 2006, 74 percent of hatchback twin buyers bought a diesel hatchback, and 59 percent of sedan twin buyers bought a diesel sedan; these percentages have risen steadily since 2002. Clearly, the majority of "twin" buyers realized significant savings. Does this mean that the buyers of petrol

\footnotetext{
19 This is based on $10 \mathrm{kpl}$ for a petrol hatchback and $13 \mathrm{kpl}$ for a diesel hatchback.

${ }^{20}$ At $9 \mathrm{kpl}$, the petrol sedan would cost 30/9=3.33 Rs. per kilometer if petrol cost the same per liter as diesel. Increasing fuel economy from 9 to $12 \mathrm{kpl}$ reduces the cost per kilometer from 3.33 to 2.5 Rs. So 1.67 Rs. of the 2.5Rs. reduction in cost comes from the lower cost of diesel fuel.
} 
twins undervalued fuel savings? As Table 11 shows, diesel and petrol twins differ noticeably in weight and in performance: diesel twins are generally heavier and less powerful than their petrol counterparts. It could be that buyers of petrol twins value these characteristics enough to forgo the fuel savings from buying a diesel.

\subsection{The Value Petrol Car Buyers Place on the Petrol Twin}

It is straightforward to show that the fuel savings forgone by petrol car buyers (equation [6]) is a lower bound to the money these buyers would have to receive to keep their utility constant if they were forced to buy the diesel twin. Let $x^{*}$ denote the income remaining after the petrol car buyer purchases a petrol car $\left(Z_{p}\right)$ and drives $K^{*}$ miles. Let $x^{\prime}$ denote the income remaining if he drives $K^{*}$ kilometers but buys the diesel twin $\left(Z_{d}\right)$. If the buyer is rational, he prefers $\left(x^{*}, Z_{p}, K^{*}\right)$ to $\left(x^{\prime}, Z_{d}, K^{*}\right)$; that is,

$$
U\left(x^{*}, Z_{p}, K^{*}\right)>U\left(x^{\prime}, Z_{d}, K^{*}\right)
$$

There is, however, some amount of money, $\hat{x}$, that will make him as happy as with the petrol twin, defined by

$$
U\left(x^{*}, Z_{p}, K^{*}\right)=U\left(\hat{x}^{\prime}, Z_{d}, K^{*}\right)
$$

To keep his utility constant, the amount the petrol buyer would have to be given (his compensating variation) if forced to buy a diesel car is $\hat{x}-x^{*}$. Because $\hat{x}>x^{\prime}, x^{\prime}-x^{*}$ is a lower bound to this value. From equation (2), $x^{\prime}-x^{*}$ equals the net value of fuel savings from buying a diesel; that is, equation (6) evaluated at $K^{*}$.

This implies that the lower bound to the value placed on characteristics $Z_{p}\left(\mathrm{v} . Z_{d}\right)$ is approximately 100,000 Rs. for buyers of petrol hatchbacks and 150,000 Rs. for buyers of petrol sedans. It is, of course, impossible to say whether this is rational. To judge how these car buyers valued fuel economy requires estimating a model of the demand for vehicle characteristics (see, e.g., Allcott and Wozny 2010).

\section{Conclusion}

The debate over mitigating the environmental impact of India's rapidly expanding vehicle fleet has centered on reducing fuel consumption. One commonly cited justification for fuel economy standards, as opposed to higher fuel taxes, is the belief that consumers undervalue fuel economy when making purchasing decisions. We have addressed this concern by comparing 
the cost to consumers of increased fuel economy to the associated fuel savings. Based on our IV estimates of hedonic price functions, we cannot reject the null hypothesis that the mean consumer equates the marginal price of fuel economy to the present value of fuel savings in the markets for petrol hatchbacks and petrol sedans. In the markets for diesel hatchbacks and diesel sedans, however, we reject the null hypothesis for at least some specifications in all years. In the cases for which we can reject the null hypothesis, consumers appear to be overvaluing fuel economy and, therefore, buying too much of it rather than too little.

To further understand the trade-offs faced by consumers, we considered the choices faced by potential buyers of twins. Diesel versions of twins are, in general, more expensive than their petrol counterparts but have sufficiently lower operating costs as to more than offset the difference in purchase price. Net savings from purchasing a diesel twin are substantial. By choosing their vehicle over its petrol twin, diesel hatchback owners save the equivalent of 44 percent of the purchase price of their chosen vehicle; diesel sedan owners save 23 percent. In 2006, 74 percent of twin hatchback owners and 59 percent of twin sedan owners realized these savings by buying the diesel twin. Because of their lower monthly driving distance, forgone savings by owners of petrol twins are lower, but still substantial: petrol hatchback owners could have saved (on net) 23 percent of the purchase price of their chosen vehicles, and sedan owners 15 percent, by buying a diesel. This does not mean that buyers of petrol twins were irrational; they may have been willing to forgo these savings to drive a more powerful petrol vehicle.

There are limits to what can be said using the data on vehicle characteristics and sales prices used in this paper. The next step in our analysis is to estimate models of vehicle demand and miles driven using individual household data on vehicle purchases. These models can be used to compute the welfare effects of changes in fuel taxes (e.g., the impact of equalizing the cost of diesel and petrol) and of imposing fuel economy standards. If, for example, auto manufacturers in India were to meet fuel economy standards by reducing vehicle weight and horsepower, as was done in the United States (Klier and Linn 2008), this could result in a welfare loss to Indian consumers. To justify such an intervention, these losses should be compared to the welfare gains from reduced pollution, congestion, and dependence on foreign oil. Such a comparison of costs and benefits cannot be accomplished without first quantifying both. 


\section{References}

Alcott, H., and N. Wozny. 2010. Gasoline Prices, Fuel Economy, and the Energy Paradox. Center for Energy and Environmental Policy Research working paper 10-003. Cambridge, MA: Center for Energy and Environmental Policy Research.

Anderson, S., R. Kellogg, and J. Sallee. 2010. What Do Consumers Believe about Future Gasoline Prices? Unpublished manuscript.

Atkinson, S.E., and R. Halvorsen. 1984. A New Hedonic Technique For Estimating Attribute Demand: An Application to the Demand for Automobile Efficiency. The Review of Economics and Statistics 66(3): 417-426.

Bureau of Transportation Statistics. 2008. http://www.bts.gov/publications/national_transportation_statistics/2008/html/table_01_25 $\underline{. h t m l}$

Carazoo. No date. Car Loans_-More Than Meets the Eye. http://www.carazoo.com/article/1606200801/Car-Loans---More-Than-Meets-the-Eye (accessed March 7, 2011).

Chugh, R., M. Cropper, and U. Narain. 2010. The Demand for Fuel Economy in the Indian Passenger Vehicle Market. Paper presented at the American Social Sciences Association meetings. Atlanta, GA.

Espey, M., and S. Nair. 2005. Automobile Fuel Economy: What Is It Worth? Contemporary Economic Policy 23(3), 317-323.

Greene, D. 2010. How Consumers Value Fuel Economy: A Literature Review. Office of Transportation and Air Quality. EPA-420-R-10-008. Washington, DC: U.S. Environmental Protection Agency.

Helfand, G., and A. Wolverton. 2010. Evaluating the Consumer Response to Fuel Economy: A Review of the Literature. Discussion paper. National Center for Environmental Economics. Washington, DC: U.S. Environmental Protection Agency.

Klier, T., and J. Linn. 2008. New Vehicle Characteristics and the Cost of the Corporate Average Fuel Economy Standard. Federal Reserve Bank of Chicago working paper series WP-0813. Chicago, IL: Federal Reserve Bank of Chicago. 
Klier, T., and J. Linn. 2009. The Price of Gasoline and the Demand for Fuel Economy: Evidence from Monthly Vehicle Sales Data. Federal Reserve Bank of Chicago working paper series 2009-15. Chicago, IL: Federal Reserve Bank of Chicago.

Li, S., C. Timmins, and R. von Haefen. 2009. How Do Gasoline Prices Affect Fleet Fuel Economy? American Economic Journal: Economic Policy 1(2): 113-137.

Rogers, John Allen. 2009. Personal Communication.

Sallee, J., S. West, and W. Fan. 2010. The Effect of Gasoline Prices on the Demand for Fuel Economy in Used Vehicles: Empirical Evidence and Policy Implications. Paper presented at the World Congress of Environmental and Resource Economists. Montreal, Canada.

Shankar, Neelima. 2007. Auto Loan Interest Rates Slashed by Bank of India. Rupee Times, Oct 17.

http://www.rupeetimes.com/news/car_loans/auto_loan_interest_rates_slashed_by_bank_ of_india_1079.html (accessed March 7, 2011).

Seth, Yogima. 2009. Auto Lenders Set To Revise Interest Rates. The Financial Express, Jan 7. http://www.financialexpress.com/news/auto-lenders-set-to-revise-interest-rates/407419/ (accessed March 7, 2011).

U.S. EPA (Environmental Protection Agency). 2008. Light-Duty Automotive Technology and Fuel Economy Trends: 1975 through 2008. Office of Transportation and Air Quality. Washington, DC: U.S. EPA. 


\section{Tables and Figures}

Table 1. Sales-Weighted Model-Level Summary Statistics

\begin{tabular}{l|c|llll}
\hline \multirow{2}{*}{ Variables } & Units & $\begin{array}{l}\text { Petrol } \\
\text { hatchback }\end{array}$ & $\begin{array}{l}\text { Diesel } \\
\text { hatchback }\end{array}$ & $\begin{array}{l}\text { Petrol } \\
\text { sedan }\end{array}$ & $\begin{array}{l}\text { Diesel } \\
\text { sedan }\end{array}$ \\
\hline Price & $10^{5}$ Rupees 2008 & 4.09 & 4.63 & 8.76 & 8.62 \\
Kerb weight & (USD 2008) & $(10,400)$ & $(11,800)$ & $(22,200)$ & $(21,900)$ \\
& $1,000 \mathrm{~kg}$ & 0.773 & 0.976 & 1.04 & 1.13 \\
Power ratio & (Ibs) & $(1,700)$ & $(2,150)$ & $(2,300)$ & $(2,490)$ \\
& $\mathrm{hp} / \mathrm{kg}$ & 0.0707 & 0.0559 & 0.0892 & 0.0607 \\
Engine size & (hp/lb) & $(0.0321)$ & $(0.0254)$ & $(0.0405)$ & $(0.0275)$ \\
Torque & $\mathrm{cC}$ & 972 & 1,420 & 1,540 & 1,570 \\
& $\mathrm{~kg}-\mathrm{m}$ & 7.89 & 9.00 & 13.0 & 14.9 \\
City fuel economy & (ft-lb) & $(57.0)$ & $(65.1)$ & $(94.1)$ & $(108)$ \\
& $\mathrm{kpl}$ & 12.1 & 13.0 & 9.60 & 12.3 \\
Luxury index & (mpg) & $(28.5)$ & $(30.7)$ & $(22.6)$ & $(29.0)$ \\
Safety index & & 2.04 & 2.16 & 4.71 & 4.11 \\
Automatic & & 0.427 & 0.221 & 0.889 & 0.978 \\
Distance driven & $\mathrm{km} / \mathrm{month}$ & 1,070 & 1,870 & 1,300 & 1,870 \\
& $(\mathrm{miles} / \mathrm{month})$ & $(663)$ & $(1,160)$ & $(808)$ & $(1,160)$ \\
\# of models & & 43 & 12 & 72 & 31 \\
\hline
\end{tabular}

Notes: Each model is available in multiple versions. For each year, and for each vehicle category, model/fuel-type level vehicle characteristics are constructed as the unweighted average across all available versions of each model for each fuel type. The within-year sales-weighted average of these models is calculated for each vehicle category. The resulting year representative vehicles are averaged across years 2002 to 2006 and presented above. The operating cost represents present discounted value of fuel expenditures over life of vehicle using a 15percent discount rate. Hatchbacks are assumed to last 11 years, sedans 12 years. Fuel prices are held constant at average price in the year of purchase. Source: Version-level vehicle characteristics data come from AutoCar India. Modellevel market share data come from the J.D. Power APEAL survey. 


\section{Table 2. Version-Level Summary Statistics (Standard Deviations in Parentheses)}

\begin{tabular}{|c|c|c|c|c|c|}
\hline Variables & Units & \begin{tabular}{|l|} 
Petrol \\
hatchback
\end{tabular} & $\begin{array}{l}\text { Diesel } \\
\text { hatchback }\end{array}$ & $\begin{array}{l}\text { Petrol } \\
\text { sedan }\end{array}$ & $\begin{array}{l}\text { Diesel } \\
\text { sedan }\end{array}$ \\
\hline \multirow[t]{2}{*}{ Price } & $10^{5}$ Rupees 2008 & 4.71 & 4.84 & 14.3 & 13.0 \\
\hline & & (1.42) & $(0.758)$ & (15.8) & (9.24) \\
\hline \multirow[t]{2}{*}{ Kerb weight } & $1,000 \mathrm{~kg}$ & 0.907 & 0.991 & 1.19 & 1.22 \\
\hline & & $(0.155)$ & $(0.095)$ & $(0.219)$ & $(0.170)$ \\
\hline \multirow[t]{2}{*}{ Power ratio } & $\mathrm{hp} / \mathrm{kg}$ & 0.0749 & 0.0603 & 0.0946 & 0.0666 \\
\hline & & (0.00906) & $(0.00900)$ & $(0.0191)$ & (0.0175) \\
\hline \multirow[t]{2}{*}{ Engine size } & cC & 1,160 & 1,570 & 1,810 & 1,810 \\
\hline & & (244) & (220) & $(580)$ & (317) \\
\hline \multirow[t]{2}{*}{ Torque } & kg-m & 9.81 & 10.8 & 16.1 & 18.4 \\
\hline & & (2.32) & (2.85) & $(6.04)$ & (8.47) \\
\hline \multirow[t]{2}{*}{ City fuel economy } & kpl & 11.0 & 13.1 & 8.70 & 11.6 \\
\hline & & (1.42) & (1.12) & (1.37) & (1.67) \\
\hline \multirow[t]{2}{*}{ Luxury index } & & 2.91 & 2.48 & 5.82 & 5.50 \\
\hline & & (1.73) & (1.47) & (2.56) & (2.62) \\
\hline \multirow[t]{2}{*}{ Safety index } & & 0.775 & 0.781 & 1.71 & 1.61 \\
\hline & & $(0.727)$ & $(0.766)$ & (1.41) & (1.46) \\
\hline \multirow[t]{2}{*}{ Automatic } & & 0.041 & 0.000 & 0.212 & 0.146 \\
\hline & & (0.199) & 0.000 & $(0.409)$ & $(0.354)$ \\
\hline \# of versions & & 244 & 64 & 411 & 158 \\
\hline
\end{tabular}

Notes: For each vehicle category, the unweighted average across all available versions from years 2002 to 2008 is presented above with standard deviations in parentheses.

Source: Version level vehicle characteristics data come from AutoCar India.

Table 3. Explanatory Variables

\begin{tabular}{l|l}
\hline Variable & \multicolumn{1}{c}{ Description } \\
\hline Price & $\begin{array}{l}\text { Price of vehicle in Delhi } \\
\text { Mass of vehicle }\end{array}$ \\
Power ratio & $\begin{array}{l}\text { Ratio of power to vehicle mass; this variable is a key indicator of } \\
\text { vehicle performance } \\
\text { Volume of air and fuel displaced in one engine cycle; associated with } \\
\text { higher power but lower fuel economy } \\
\text { Engine torque (as opposed to torque at wheels); proportional to power } \\
\text { if both are measured at same engine speed } \\
\text { The sum of the indicator variables for air conditioning, power steering, } \\
\text { central locking, power windows, alloy wheels, leather seats, power } \\
\text { mirrors, cd player, and Carwale.com luxury rating (0-none, 1-luxury, or } \\
\text { 2-super luxury) } \\
\text { The sum of the indicator variables for airbags, rear seat belts, antilock } \\
\text { Lraking system, and traction control }\end{array}$ \\
Safety index & $\begin{array}{l}\text { An indicator variable for transmission type (0-manual or 1-automatic) } \\
\text { Fuel economy under urban driving conditions }\end{array}$ \\
Automatic &
\end{tabular}

Note: Variables used in hedonic price function analysis are presented above. 


\section{Table 4. Hedonic Price Function IV Estimation Results-Petrol Hatchback}

\begin{tabular}{|c|c|c|c|c|}
\hline \multirow[b]{3}{*}{ Variables } & \multicolumn{4}{|c|}{ Specifications } \\
\hline & (1) & (2) & (3) & (4) \\
\hline & Logdelhi2008 & Logdelhi2008 & Logdelhi2008 & Logdelhi2008 \\
\hline \multirow[t]{2}{*}{ City fuel economy } & $0.0316^{*}$ & 0.0155 & $0.0935^{* * *}$ & $0.0899 * * *$ \\
\hline & $(0.0179)$ & $(0.0302)$ & $(0.0314)$ & $(0.0285)$ \\
\hline \multirow[t]{2}{*}{ Kerb weight } & $0.975 * * *$ & $1.099 * * *$ & $0.593^{* * *}$ & $0.548^{* * *}$ \\
\hline & (0.119) & $(0.102)$ & (0.147) & $(0.130)$ \\
\hline \multirow[t]{2}{*}{ Power ratio } & $10.93 * * *$ & $12.77^{* * *}$ & & \\
\hline & (1.069) & (1.669) & & \\
\hline \multirow[t]{2}{*}{ Engine size } & & -0.000200 & & 0.000473 \\
\hline & & (0.000192) & & (0.000290) \\
\hline \multirow[t]{2}{*}{ Torque } & & & $0.0744^{* * *}$ & 0.0274 \\
\hline & & & $(0.0125)$ & $(0.0229)$ \\
\hline \multirow[t]{2}{*}{ Luxury index } & $0.0721^{* * *}$ & $0.0713^{* * *}$ & $0.0852^{* * *}$ & $0.0845^{* * *}$ \\
\hline & $(0.00512)$ & $(0.00505)$ & (0.00669) & $(0.00646)$ \\
\hline \multirow[t]{2}{*}{ Safety index } & $-0.0294 * *$ & $-0.0296 * *$ & $-0.0349 *$ & $-0.0286^{*}$ \\
\hline & $(0.0131)$ & $(0.0127)$ & (0.0181) & $(0.0166)$ \\
\hline \multirow[t]{2}{*}{ Automatic } & $0.155^{* * *}$ & $0.143^{* * *}$ & $0.163 * * *$ & $0.173 * * *$ \\
\hline & $(0.0361)$ & (0.0395) & $(0.0501)$ & (0.0511) \\
\hline \multirow[t]{2}{*}{ Y2003 } & $-0.0684 * * *$ & $-0.0759 * * *$ & -0.0328 & -0.0293 \\
\hline & $(0.0254)$ & $(0.0257)$ & $(0.0344)$ & $(0.0336)$ \\
\hline \multirow[t]{2}{*}{ Y2004 } & $-0.125^{* * *}$ & $-0.132 * * *$ & $-0.0924^{* *}$ & $-0.0927^{* * *}$ \\
\hline & $(0.0265)$ & $(0.0273)$ & $(0.0366)$ & $(0.0353)$ \\
\hline \multirow[t]{2}{*}{ Y2005 } & $-0.208 * * *$ & $-0.218 * * *$ & $-0.174 * * *$ & $-0.163 * * *$ \\
\hline & $(0.0251)$ & $(0.0268)$ & $(0.0342)$ & $(0.0346)$ \\
\hline \multirow[t]{2}{*}{ Y2006 } & $-0.149 * * *$ & $-0.159 * * *$ & $-0.125^{* * *}$ & $-0.115^{* * *}$ \\
\hline & $(0.0256)$ & $(0.0280)$ & (0.0354) & $(0.0363)$ \\
\hline \multirow[t]{2}{*}{ Y2007 } & $-0.268 * * *$ & $-0.273 * * *$ & $-0.305^{* * *}$ & $-0.278 * * *$ \\
\hline & $(0.0258)$ & $(0.0251)$ & $(0.0355)$ & $(0.0355)$ \\
\hline \multirow[t]{2}{*}{ Y2008 } & $-0.290 * * *$ & $-0.300 * * *$ & $-0.326 * * *$ & $-0.289 * * *$ \\
\hline & $(0.0246)$ & $(0.0257)$ & $(0.0331)$ & $(0.0381)$ \\
\hline \multirow[t]{2}{*}{ Constant } & $-0.580^{*}$ & -0.410 & $-0.868 *$ & $-0.894^{*}$ \\
\hline & $(0.346)$ & $(0.462)$ & $(0.522)$ & $(0.519)$ \\
\hline Observations & 236 & 236 & 236 & 236 \\
\hline R-squared & 0.881 & 0.888 & 0.781 & 0.794 \\
\hline
\end{tabular}

Notes: This table presents hedonic price function IV estimation results using petrol hatchbacks for years 2002 to 2008. To analyze robustness of results, we present four different specifications. Standard errors are in parentheses, $* * * \mathrm{p}<0.01, * * \mathrm{p}<0.05, * \mathrm{p}<0.1$ 


\section{Table 5. Hedonic Price Function IV Estimation Results-Diesel Hatchback}

\begin{tabular}{|c|c|c|c|c|}
\hline \multirow[b]{3}{*}{ Variables } & \multicolumn{4}{|c|}{ Specifications } \\
\hline & (1) & (2) & (3) & (4) \\
\hline & Logdelhi2008 & Logdelhi2008 & Logdelhi2008 & 3 Logdelhi2008 \\
\hline \multirow[t]{2}{*}{ City fuel economy } & $0.0734^{* * *}$ & $0.0873^{* * *}$ & $0.0633^{* * *}$ & $0.0830 * * *$ \\
\hline & $(0.0182)$ & $(0.0181)$ & $(0.0192)$ & $(0.0193)$ \\
\hline \multirow[t]{2}{*}{ Kerb weight } & $1.308^{* * *}$ & $1.180 * * *$ & $0.784^{* * *}$ & $0.753^{* * *}$ \\
\hline & $(0.158)$ & (0.189) & $(0.175)$ & $(0.188)$ \\
\hline \multirow[t]{2}{*}{ Power ratio } & $6.721 * * *$ & $5.412 * * *$ & & \\
\hline & (1.189) & $(1.335)$ & & \\
\hline \multirow[t]{2}{*}{ Engine size } & & $0.000127^{* *}$ & & $0.000156^{* * *}$ \\
\hline & & $(6.23 e-05)$ & & (5.99e-05) \\
\hline \multirow{2}{*}{ Torque } & & & $0.0213^{* * *}$ & $0.0161^{* * *}$ \\
\hline & & & $(0.00407)$ & $(0.00444)$ \\
\hline \multirow[t]{2}{*}{ Luxury index } & $0.0376^{* * *}$ & $0.0385^{* * *}$ & $0.0392 * * *$ & $0.0399 * * *$ \\
\hline & $(0.00688)$ & $(0.00727)$ & $(0.00671)$ & $(0.00713)$ \\
\hline \multirow[t]{2}{*}{ Safety index } & 0.000191 & -0.0131 & 0.000624 & -0.0158 \\
\hline & $(0.0141)$ & $(0.0156)$ & (0.0139) & $(0.0154)$ \\
\hline \multirow{2}{*}{ Automatic } & 0 & 0 & 0 & 0 \\
\hline & (0) & (0) & (0) & (0) \\
\hline \multirow[t]{2}{*}{ Y2003 } & $-0.0575^{* *}$ & $-0.0651^{* *}$ & $-0.0617^{* *}$ & $-0.0700 * *$ \\
\hline & $(0.0293)$ & $(0.0311)$ & $(0.0290)$ & $(0.0310)$ \\
\hline \multirow[t]{2}{*}{ Y2004 } & $-0.150 * * *$ & $-0.150 * * *$ & $-0.146 * * *$ & $-0.147^{* * *}$ \\
\hline & $(0.0291)$ & $(0.0305)$ & $(0.0286)$ & $(0.0302)$ \\
\hline \multirow[t]{2}{*}{ Y2005 } & $-0.0905^{* *}$ & $-0.0672^{*}$ & $-0.0990 * *$ & $-0.0682^{*}$ \\
\hline & $(0.0392)$ & $(0.0404)$ & $(0.0392)$ & $(0.0408)$ \\
\hline \multirow[t]{2}{*}{ Y2006 } & -0.000269 & 0.0391 & -0.0132 & 0.0384 \\
\hline & $(0.0432)$ & $(0.0453)$ & $(0.0432)$ & $(0.0459)$ \\
\hline \multirow[t]{2}{*}{ Y2007 } & $-0.144 * * *$ & $-0.0991^{* *}$ & $-0.156 * * *$ & $-0.0978 * *$ \\
\hline & $(0.0408)$ & $(0.0437)$ & $(0.0413)$ & $(0.0445)$ \\
\hline \multirow[t]{2}{*}{ Y2008 } & $-0.236 * * *$ & $-0.169 * * *$ & $-0.257 * * *$ & $-0.168^{* * *}$ \\
\hline & $(0.0413)$ & $(0.0493)$ & $(0.0440)$ & $(0.0517)$ \\
\hline \multirow[t]{2}{*}{ Constant } & $-1.091^{* * *}$ & $-1.281 * * *$ & -0.260 & $-0.695^{*}$ \\
\hline & $(0.351)$ & $(0.353)$ & $(0.384)$ & $(0.390)$ \\
\hline Observations & 64 & 64 & 64 & 64 \\
\hline R-squared & 0.851 & 0.836 & 0.856 & 0.839 \\
\hline
\end{tabular}

Notes: This table presents hedonic price function IV estimation results using diesel hatchbacks for years 2002 to 2008. To analyze robustness of results, we present four different specifications. Standard errors are in parentheses, $* * * \mathrm{p}<0.01, * * \mathrm{p}<0.05, * \mathrm{p}<0.1$ 
Table 6. Hedonic Price Function IV Estimation Results-Petrol Sedan

\begin{tabular}{|c|c|c|c|c|}
\hline \multirow[b]{3}{*}{ Variables } & \multicolumn{4}{|c|}{ Specifications } \\
\hline & (1) & (2) & (3) & (4) \\
\hline & Logdelhi2008 & Logdelhi2008 & Logdelhi2008 & Logdelhi2008 \\
\hline \multirow[t]{2}{*}{ City fuel economy } & $0.0484^{* *}$ & $0.0597^{* * *}$ & $0.0699 * *$ & $0.0843 * * *$ \\
\hline & $(0.0220)$ & $(0.0197)$ & $(0.0306)$ & $(0.0304)$ \\
\hline \multirow[t]{2}{*}{ Kerb weight } & $1.355^{* * *}$ & $0.914^{* * *}$ & $0.828 * * *$ & $0.742 * * *$ \\
\hline & $(0.112)$ & $(0.138)$ & $(0.138)$ & $(0.137)$ \\
\hline \multirow[t]{2}{*}{ Power ratio } & $5.984 * * *$ & $3.344 * * *$ & & \\
\hline & $(0.863)$ & $(0.960)$ & & \\
\hline \multirow[t]{2}{*}{ Engine size } & & $0.000442 * * *$ & & $0.000461^{* * *}$ \\
\hline & & $(6.75 e-05)$ & & (8.95e-05) \\
\hline \multirow[t]{2}{*}{ Torque } & & & $0.0485^{* * *}$ & $0.0176 * *$ \\
\hline & & & $(0.00580)$ & $(0.00830)$ \\
\hline \multirow[t]{2}{*}{ Luxury index } & $0.0513^{* * *}$ & $0.0453^{* * *}$ & $0.0471^{* * *}$ & $0.0437 * * *$ \\
\hline & $(0.00481)$ & $(0.00443)$ & (0.00509) & (0.00508) \\
\hline \multirow[t]{2}{*}{ Safety index } & 0.0117 & $0.0159 *$ & $0.0198 *$ & $0.0264 * *$ \\
\hline & $(0.00965)$ & $(0.00886)$ & (0.0111) & $(0.0110)$ \\
\hline \multirow[t]{2}{*}{ Automatic } & $0.108 * * *$ & 0.0513 & 0.0785 & 0.0614 \\
\hline & $(0.0407)$ & $(0.0397)$ & $(0.0484)$ & $(0.0479)$ \\
\hline \multirow[t]{2}{*}{ Y2003 } & -0.0256 & -0.0192 & -0.0114 & -0.00107 \\
\hline & $(0.0292)$ & $(0.0268)$ & $(0.0335)$ & $(0.0332)$ \\
\hline \multirow[t]{2}{*}{ Y2004 } & $-0.149 * * *$ & $-0.159 * * *$ & $-0.147^{* * *}$ & $-0.149 * * *$ \\
\hline & $(0.0270)$ & $(0.0251)$ & $(0.0301)$ & $(0.0298)$ \\
\hline \multirow[t]{2}{*}{ Y2005 } & $-0.228^{* * *}$ & $-0.222 * * *$ & $-0.204 * * *$ & $-0.191 * * *$ \\
\hline & $(0.0337)$ & $(0.0309)$ & $(0.0417)$ & $(0.0413)$ \\
\hline \multirow[t]{2}{*}{ Y2006 } & $-0.266 * * *$ & $-0.261 * * *$ & $-0.275^{* * *}$ & $-0.258 * * *$ \\
\hline & $(0.0281)$ & $(0.0258)$ & $(0.0304)$ & $(0.0303)$ \\
\hline \multirow[t]{2}{*}{ Y2007 } & $-0.304 * * *$ & $-0.280 * * *$ & $-0.314^{* * *}$ & $-0.276 * * *$ \\
\hline & $(0.0269)$ & $(0.0247)$ & $(0.0290)$ & $(0.0297)$ \\
\hline \multirow[t]{2}{*}{ Y2008 } & $-0.391 * * *$ & $-0.361 * * *$ & $-0.407^{* * *}$ & $-0.362^{* * *}$ \\
\hline & $(0.0291)$ & $(0.0270)$ & $(0.0306)$ & $(0.0315)$ \\
\hline \multirow[t]{2}{*}{ Constant } & -0.450 & -0.512 & -0.176 & -0.529 \\
\hline & $(0.356)$ & $(0.325)$ & $(0.417)$ & $(0.418)$ \\
\hline Observations & 216 & 216 & 216 & 216 \\
\hline R-squared & 0.905 & 0.919 & 0.897 & 0.899 \\
\hline
\end{tabular}

Notes: This table presents hedonic price function IV estimation results using petrol sedans for years 2002 to 2008 . To analyze robustness of results, we present four different specifications. Standard errors are in parentheses, *** $\mathrm{p}<0.01, * * \mathrm{p}<0.05,{ }^{*} \mathrm{p}<0.1$ 
Table 7. Hedonic Price Function IV Estimation Results-Diesel Sedan

\begin{tabular}{|c|c|c|c|c|}
\hline \multirow[b]{3}{*}{ Variables } & \multicolumn{4}{|c|}{ Specifications } \\
\hline & (1) & $(2)$ & (3) & (4) \\
\hline & Logdelhi2008 & Logdelhi2008 & Logdelhi2008 & Logdelhi2008 \\
\hline \multirow[t]{2}{*}{ City fuel economy } & $0.0973 * *$ & $0.0398 *$ & $0.103^{* * *}$ & $0.0447^{* *}$ \\
\hline & $(0.0383)$ & $(0.0210)$ & $(0.0272)$ & $(0.0177)$ \\
\hline \multirow[t]{2}{*}{ Kerb weight } & $1.856 * * *$ & $1.146 * * *$ & $1.843^{* * *}$ & $0.677^{* *}$ \\
\hline & $(0.447)$ & $(0.271)$ & $(0.470)$ & $(0.338)$ \\
\hline \multirow[t]{2}{*}{ Power ratio } & 1.557 & $7.269 * * *$ & & \\
\hline & (3.573) & (2.091) & & \\
\hline \multirow[t]{2}{*}{ Engine size } & & $0.000129 * *$ & & $0.000201 * * *$ \\
\hline & & (4.99e-05) & & $(5.24 \mathrm{e}-05)$ \\
\hline \multirow[t]{2}{*}{ Torque } & & & 0.00350 & $0.0228 * * *$ \\
\hline & & & $(0.00759)$ & (0.00555) \\
\hline \multirow[t]{2}{*}{ Luxury index } & $0.0367^{* * *}$ & $0.0418^{* * *}$ & $0.0362^{* * *}$ & $0.0411^{* * *}$ \\
\hline & $(0.0104)$ & $(0.00792)$ & $(0.0101)$ & $(0.00751)$ \\
\hline \multirow[t]{2}{*}{ Safety index } & -0.000268 & -0.0208 & 0.000541 & -0.0255 \\
\hline & $(0.0240)$ & $(0.0195)$ & $(0.0237)$ & $(0.0189)$ \\
\hline \multirow[t]{2}{*}{ Automatic } & 0 & 0 & 0 & 0 \\
\hline & (0) & (0) & (0) & (0) \\
\hline \multirow[t]{2}{*}{ Y2003 } & 0.145 & -0.0165 & $0.158^{*}$ & -0.0190 \\
\hline & $(0.113)$ & $(0.0727)$ & $(0.0920)$ & $(0.0672)$ \\
\hline \multirow[t]{2}{*}{ Y2004 } & 0.0308 & $-0.128 *$ & 0.0419 & $-0.140 * *$ \\
\hline & $(0.111)$ & $(0.0720)$ & $(0.0925)$ & $(0.0677)$ \\
\hline \multirow[t]{2}{*}{ Y2005 } & 0.0848 & -0.126 & 0.102 & $-0.128 *$ \\
\hline & $(0.140)$ & $(0.0843)$ & (0.109) & $(0.0767)$ \\
\hline \multirow[t]{2}{*}{ Y2006 } & 0.136 & -0.0898 & 0.154 & -0.0976 \\
\hline & (0.149) & $(0.0889)$ & $(0.117)$ & $(0.0820)$ \\
\hline \multirow[t]{2}{*}{ Y2007 } & 0.0714 & $-0.161^{*}$ & 0.0900 & $-0.164 * *$ \\
\hline & (0.152) & $(0.0903)$ & $(0.117)$ & $(0.0818)$ \\
\hline \multirow[t]{2}{*}{ Y2008 } & 0.0119 & $-0.230 * *$ & 0.0318 & $-0.228^{* * *}$ \\
\hline & $(0.162)$ & $(0.0965)$ & $(0.122)$ & (0.0859) \\
\hline \multirow[t]{2}{*}{ Constant } & $-1.578 *$ & -0.462 & $-1.597 * *$ & 0.0221 \\
\hline & $(0.831)$ & $(0.475)$ & $(0.799)$ & $(0.527)$ \\
\hline Observations & 42 & 42 & 42 & 42 \\
\hline R-squared & 0.914 & 0.943 & 0.909 & 0.947 \\
\hline
\end{tabular}

Notes: This table presents hedonic price function IV estimation results using diesel sedans for years 2002 to 2008 . To analyze robustness of results, we present four different specifications. Standard errors are in parentheses, *** $\mathrm{p}<0.01, * * \mathrm{p}<0.05, * \mathrm{p}<0.1$ 
Table 8. OLS and IV Hedonic Price Function City Fuel Economy Coefficients

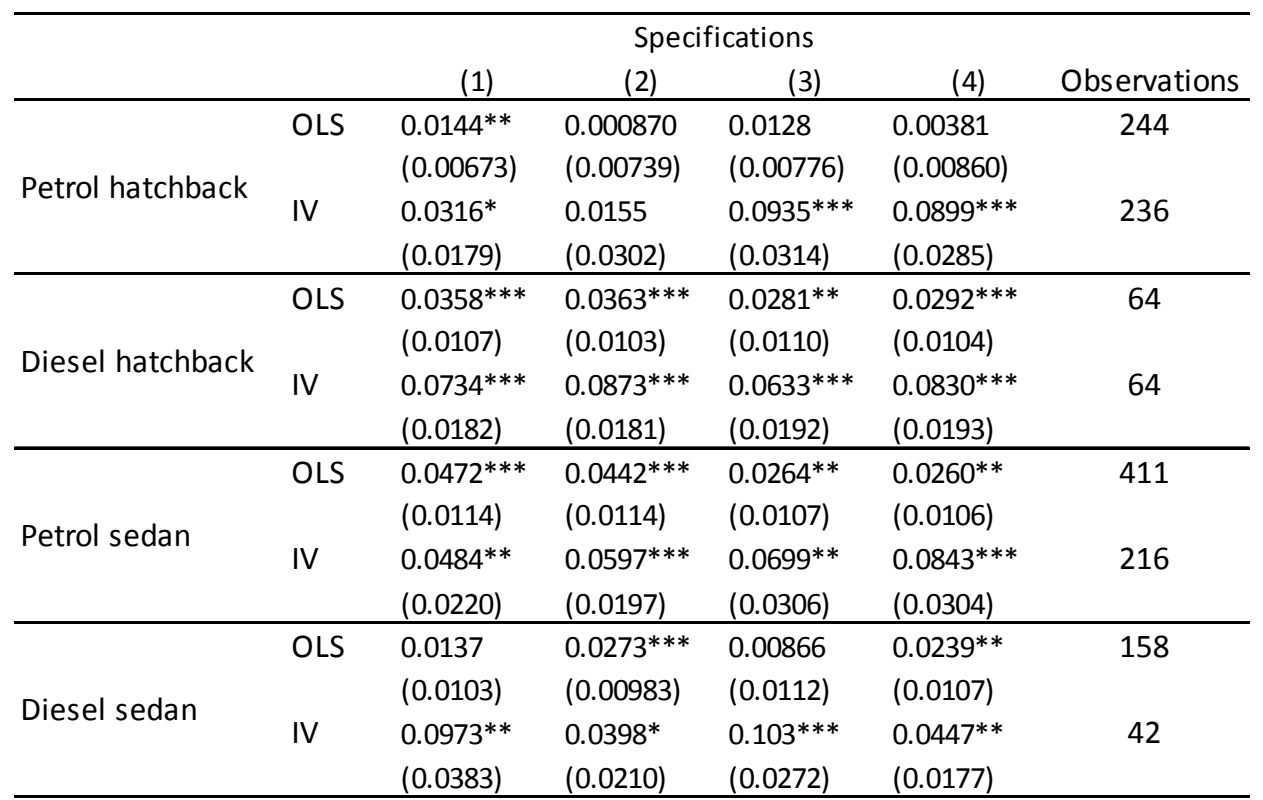

Notes: This table presents OLS and IV hedonic price function city fuel economy coefficient estimates. Standard errors in parentheses, ${ }^{* * *} \mathrm{p}<0.01,{ }^{* *} \mathrm{p}<0.05,{ }^{*} \mathrm{p}<0.1$

\section{Table 9. Fuel Economy Premium vs. Present Discounted Value of Fuel Savings,} in 2008 Rupees

\begin{tabular}{llrrrrr}
\hline & & 2002 & 2003 & 2004 & 2005 & 2006 \\
\hline & FE premium & 14,200 & 13,100 & 12,100 & 11,800 & 12,300 \\
Petrol hatchback & & $(8,240)$ & $(7,630)$ & $(6,950)$ & $(6,810)$ & $(7,130)$ \\
$(1,070 \mathrm{~km} /$ month) & Fuel cost & 213,000 & 229,000 & 258,000 & 272,000 & 289,000 \\
& PDV of fuel savings & 15,900 & 17,200 & 20,100 & 20,900 & 22,100 \\
& Percentage of fuel cost saved & 7.48 & 7.51 & 7.78 & 7.69 & 7.64 \\
\hline & FE premium & 36,900 & 37,500 & 34,000 & 32,300 & 37,400 \\
Diesel hatchback & & $(9,150)$ & $(9,730)$ & $(8,850)$ & $(7,550)$ & $(8,610)$ \\
$(1,870 \mathrm{~km} /$ month) & Fuel cost & 221,000 & 227,000 & 254,000 & 326,000 & 345,000 \\
& PDV of fuel savings & 15,700 & 15,300 & 17,100 & 24,600 & 26,000 \\
& Percentage of fuel cost saved & 7.11 & 6.76 & 6.75 & 7.54 & 7.54 \\
\hline & FE premium & 43,500 & 44,600 & 40,900 & 35,600 & 36,600 \\
Petrol sedan & & $(20,400)$ & $(20,700)$ & $(19,100)$ & $(16,200)$ & $(16,900)$ \\
$(1,300 \mathrm{~km} /$ month) & Fuel cost & 334,000 & 367,000 & 296,000 & 444,000 & 466,000 \\
& PDV of fuel savings & 30,600 & 34,400 & 36,900 & 43,300 & 44,700 \\
& Percentage of fuel cost saved & 9.15 & 9.37 & 9.31 & 9.76 & 9.59 \\
\hline & FE premium & 88,000 & 76,800 & 75,000 & 71,200 & 84,400 \\
& & $(323,800)$ & $(23,800)$ & $(24,800)$ & $(20,500)$ & $(26,600)$ \\
Diesel sedan & 228,000 & 271,000 & 287,000 & 355,000 & 358,000 \\
$(1,870 \mathrm{~km} /$ month) & Fuel cost & 16,200 & 20,900 & 21,100 & 28,100 & 27,000 \\
& PDV of fuel savings & 7.11 & 7.71 & 7.33 & 7.91 & 7.55 \\
\hline & Percentage of fuel cost saved & & & & &
\end{tabular}

Notes: FE,fuel economy; PDV, present discounted value. FE premium results are based on hedonic price function specification (1). Delta method standard errors are presented in parentheses. The present discounted value of fuel savings is calculated using a 15 percent discount rate. 
Table 10. Differences between Petrol and Diesel Twins in Price and Fuel Economy

\begin{tabular}{lllll}
\hline \multirow{2}{*}{ Variables } & \multicolumn{3}{c}{ Hatchback } & \multicolumn{2}{c}{ Sedan } \\
Diesel & $\ln ($ Price $)$ & $\ln$ (City FE) & $\ln$ (Price) & $\ln$ (City FE) \\
\hline \multirow{2}{*}{ Constant } & $0.0945^{* * *}$ & $0.271^{* * *}$ & $0.0767^{* * *}$ & $0.301^{* * *}$ \\
& $(0.0210)$ & $(0.00921)$ & $(0.00988)$ & $(0.00853)$ \\
Model-year dummies & YES & YES & YES & YES \\
Observations & $34.51^{* * *}$ & $2.37^{* * *}$ & $2.47^{* * *}$ & $2.15^{* * *}$ \\
R-squared & $(0.00819)$ & $(0.00361)$ & $(0.00475)$ & $(0.00390)$ \\
Adj R-squared & 0.815 & 314 & 689 & 579 \\
\hline
\end{tabular}

Notes: This table presents regression results using all available petrol and diesel hatchback and sedan twins for years 2002 to 2008 . Standard errors in parentheses, ${ }^{* * *} \mathrm{p}<0.01,{ }^{* *} \mathrm{p}<0.05,{ }^{*} \mathrm{p}<0.1$

Table 11. Twins-Only Version-Level Summary Statistics

\begin{tabular}{|c|c|c|c|c|c|}
\hline Variables & Units & $\begin{array}{l}\text { Petrol } \\
\text { hatchback }\end{array}$ & $\begin{array}{l}\text { Diesel } \\
\text { hatchback }\end{array}$ & $\begin{array}{l}\text { Petrol } \\
\text { sedan }\end{array}$ & $\begin{array}{l}\text { Diesel } \\
\text { sedan }\end{array}$ \\
\hline Price & $10^{5}$ Rupees 2008 & $\begin{array}{l}4.61 \\
(0.94)\end{array}$ & $\begin{array}{l}4.84 \\
(0.758)\end{array}$ & $\begin{array}{l}12.0 \\
(10.9)\end{array}$ & $\begin{array}{l}12.7 \\
(9.35)\end{array}$ \\
\hline Kerb weight & $1000 \mathrm{~kg}$ & $\begin{array}{l}0.957 \\
0.101)\end{array}$ & $\begin{array}{l}0.991 \\
(0.095)\end{array}$ & $\begin{array}{l}1.15 \\
(0.198)\end{array}$ & $\begin{array}{l}1.22 \\
(0.170)\end{array}$ \\
\hline Power ratio & $\mathrm{hp} / \mathrm{kg}$ & $\begin{array}{l}0.0761 \\
(0.00755)\end{array}$ & $\begin{array}{l}0.0603 \\
(0.00900)\end{array}$ & $\begin{array}{l}0.0896 \\
(0.0168)\end{array}$ & $\begin{array}{l}0.0658 \\
(0.0175)\end{array}$ \\
\hline Engine size & CC & $\begin{array}{l}1,280 \\
(169)\end{array}$ & $\begin{array}{l}1,570 \\
(220)\end{array}$ & $\begin{array}{l}1,680 \\
(370)\end{array}$ & $\begin{array}{l}1,800 \\
(320)\end{array}$ \\
\hline Torque & kg-m & $\begin{array}{l}10.70 \\
(1.67)\end{array}$ & $\begin{array}{l}10.8 \\
(2.85)\end{array}$ & $\begin{array}{l}15.0 \\
(4.65)\end{array}$ & $\begin{array}{l}18.0 \\
(8.40)\end{array}$ \\
\hline City fuel economy & kpl & $\begin{array}{l}10.1 \\
(1.00)\end{array}$ & $\begin{array}{l}13.1 \\
(1.12)\end{array}$ & $\begin{array}{l}8.75 \\
(1.22)\end{array}$ & $\begin{array}{l}11.6 \\
(1.69)\end{array}$ \\
\hline Luxury index & & $\begin{array}{l}2.82 \\
(1.53)\end{array}$ & $\begin{array}{l}2.48 \\
(1.47)\end{array}$ & $\begin{array}{l}5.04 \\
(2.55)\end{array}$ & $\begin{array}{l}5.33 \\
(2.57)\end{array}$ \\
\hline Safety index & & $\begin{array}{l}0.730 \\
(0.647)\end{array}$ & $\begin{array}{l}0.781 \\
(0.766)\end{array}$ & $\begin{array}{l}1.40 \\
(1.41)\end{array}$ & $\begin{array}{l}1.49 \\
(1.38)\end{array}$ \\
\hline Automatic & & $\begin{array}{l}0.000 \\
(0.000)\end{array}$ & $\begin{array}{l}0.000 \\
(0.000)\end{array}$ & $\begin{array}{l}0.133 \\
(0.341)\end{array}$ & $\begin{array}{l}0.127 \\
(0.334)\end{array}$ \\
\hline \# of versions & & 74 & 64 & 210 & 150 \\
\hline
\end{tabular}

Notes: The unweighted average across all available twin hatchback versions is presented above with standard deviations in parentheses.

Source: Version-level vehicle characteristics data come from AutoCar India. 
Figure 1. Market Shares by Body and Fuel Type, Averaged over 2002-2006

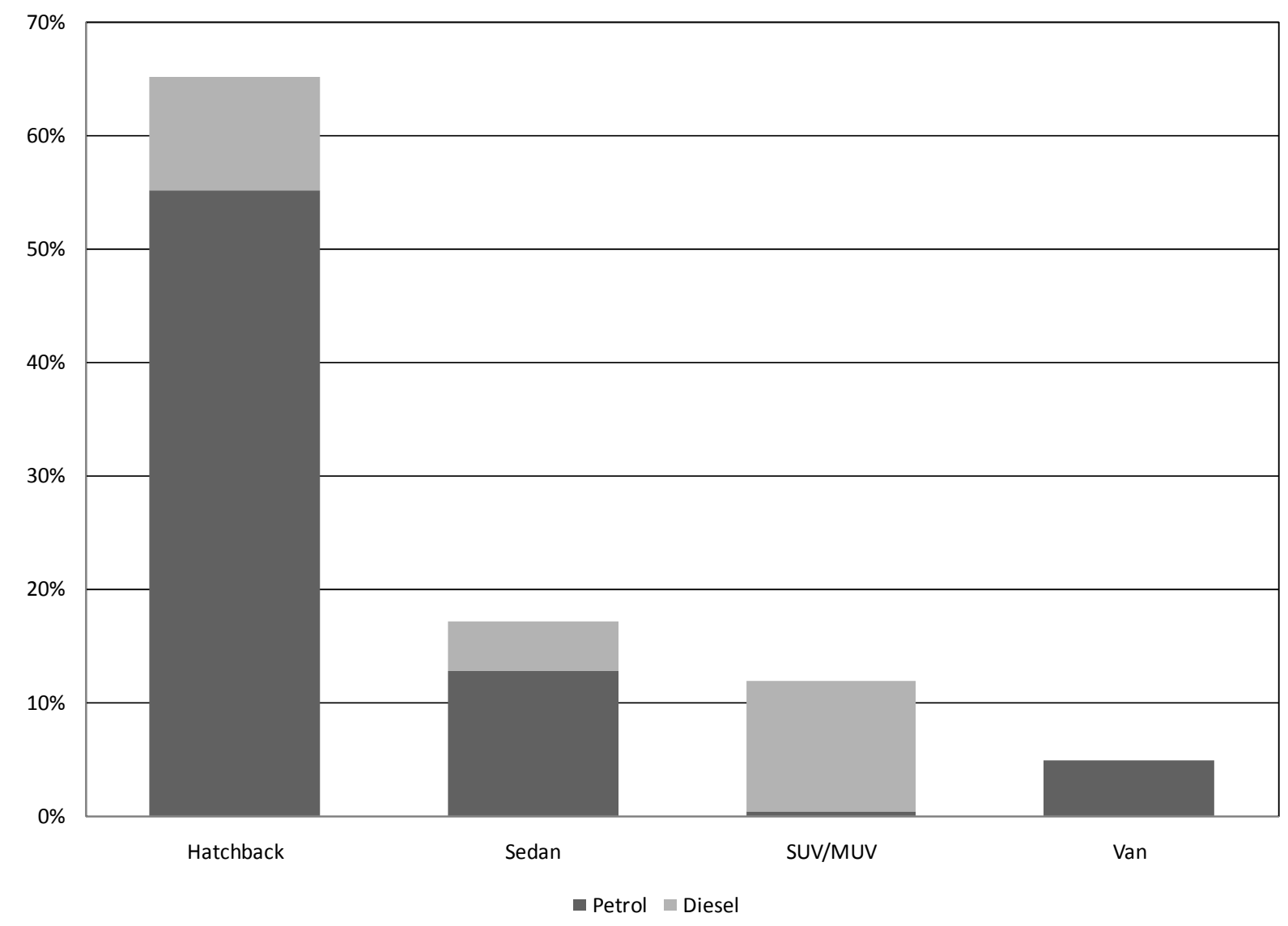

Source: Annual vehicle sales data come from the J.D. Power APEAL survey. 
Figure 2. Hatchback Market Share by Fuel Type, 2002 to 2006

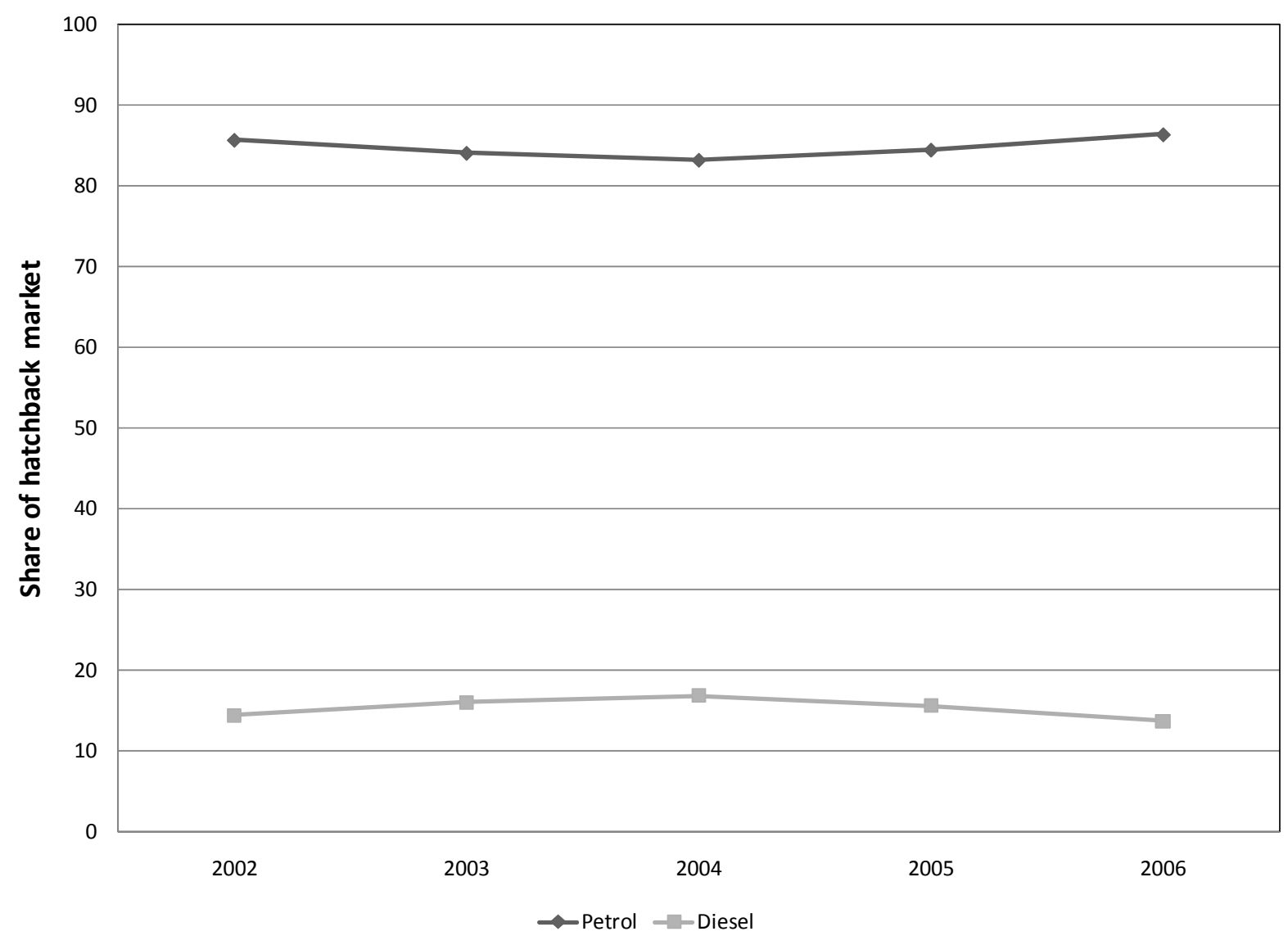

Source: Annual vehicle sales data come from the J.D. Power APEAL survey. 
Figure 3. Sedan Market Share by Fuel Type, 2002 to 2006

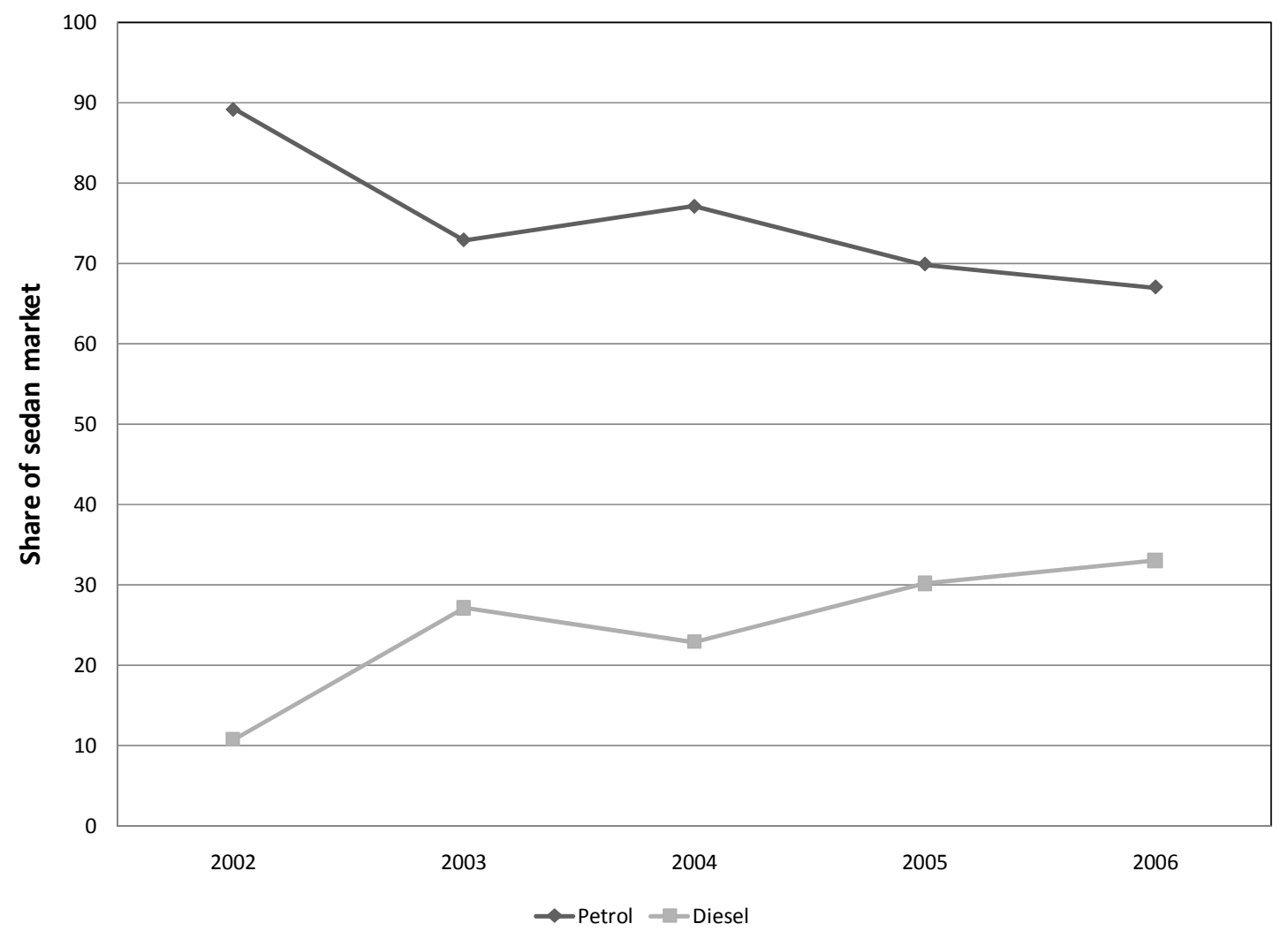

Source: Annual vehicle sales data come from the J.D. Power APEAL survey. 
Figure 4. Average Petrol and Diesel Fuel Price in Delhi, 2002 to 2006

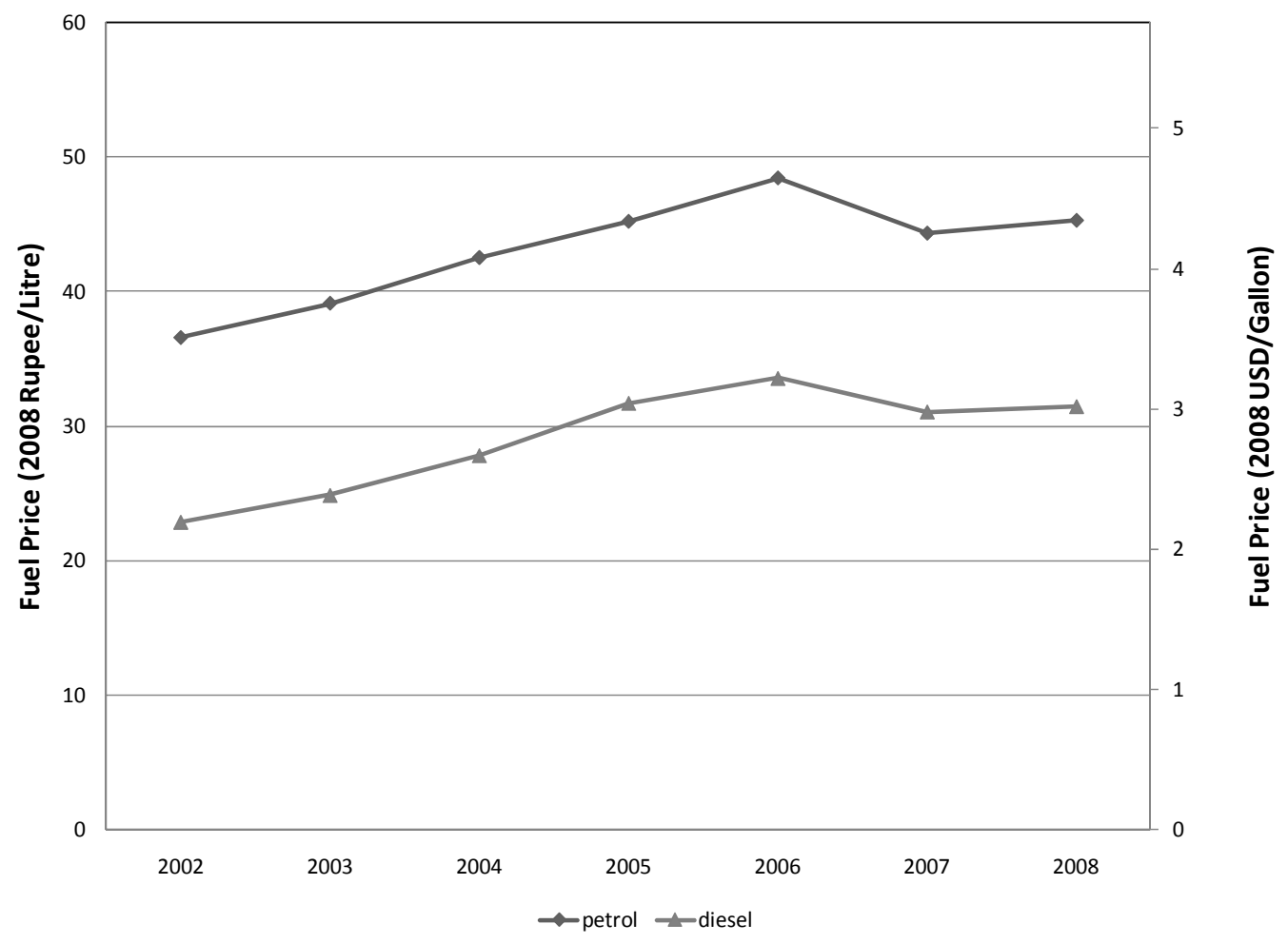

Notes: Annual average prices are constructed by weighting monthly prices by the fraction of annual vehicle sales sold in each month.

Source: Monthly Delhi fuel price data come from IndiaStat. 


\section{Figure 5. 95 Percent Confidence Intervals of Fuel Economy Premium Minus Present Discounted Value of Fuel Savings, 2002 to 2006-Petrol Hatchback}

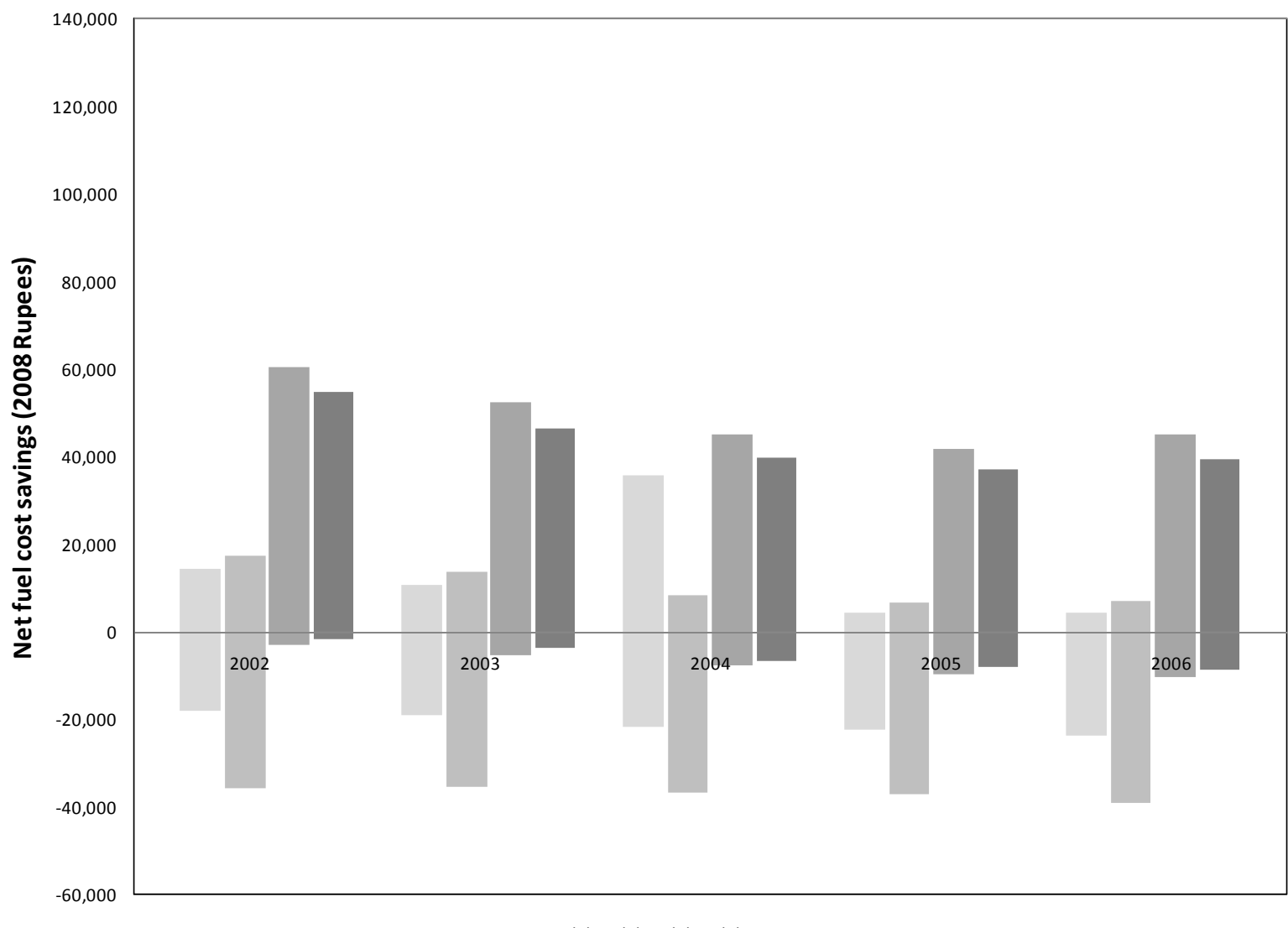

$\square(1) \square(2) \square(3) \square(4)$

Notes: The above graph presents 95 percent confidence intervals of hedonic price function estimates of the implicit marginal price of a $1 \mathrm{kpl}$ improvement in fuel economy minus the present discounted value of fuel savings that would accompany such an improvement. To demonstrate robustness across specifications, the results of four hedonic price functions are presented. The series names indicated in the legend correspond to the specification names used in Table 4. The present discounted value of fuel savings is calculated using a 15 percent discount rate. Monthly driving distance is assumed to be 1,070 kilometers for petrol hatchbacks. For any given year, the estimate of the implicit marginal price of fuel economy is the only thing that changes across specifications; the present discounted value of fuel savings is identical across all specifications. 


\section{Figure 6. 95 Percent Confidence Intervals of Fuel Economy Premium Minus Present Discounted Value of Fuel Savings, 2002 to 2006-Diesel Hatchback}

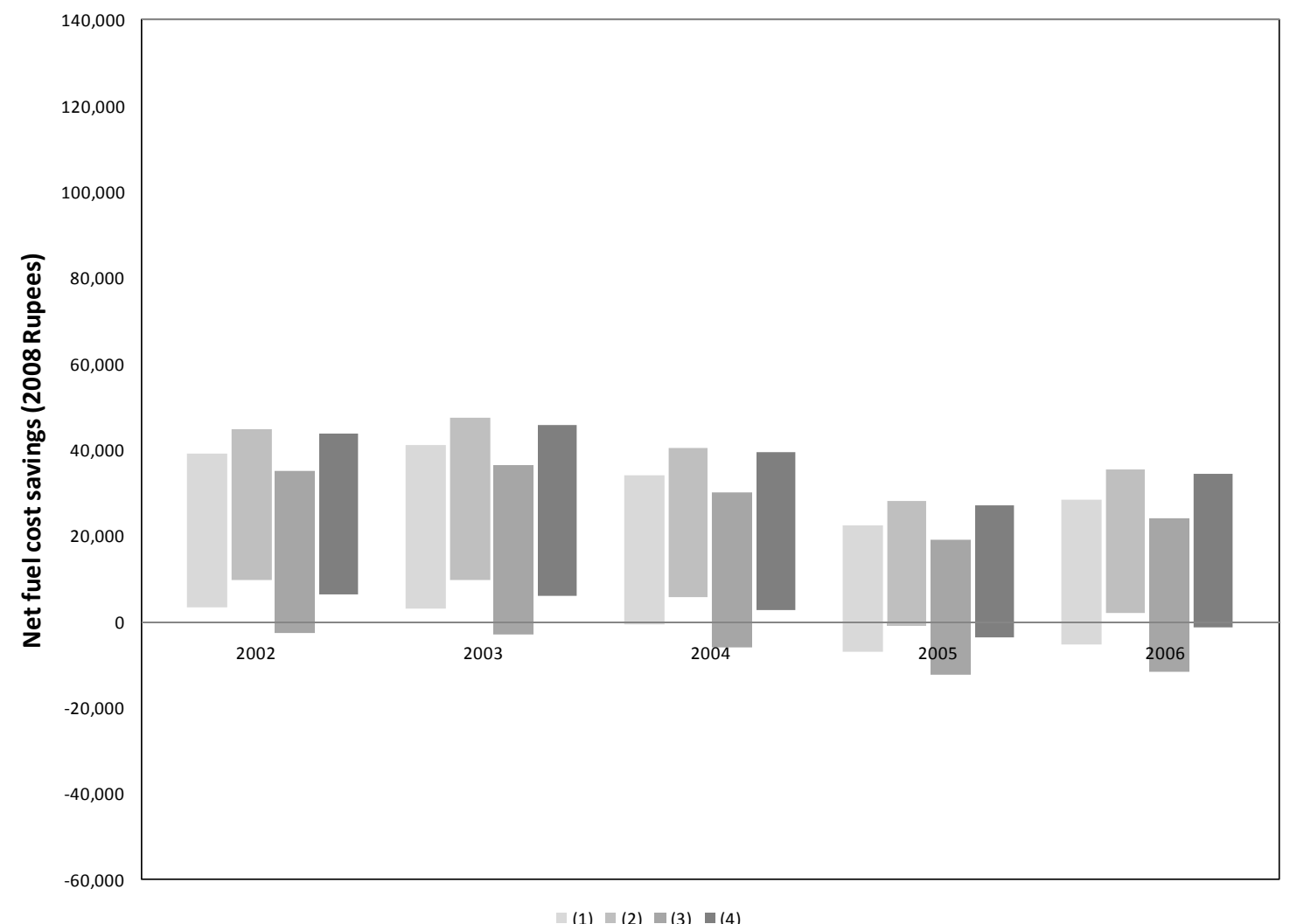

Notes: The above graph presents 95 percent confidence intervals of hedonic price function estimates of the implicit marginal price of a $1 \mathrm{kpl}$ improvement in fuel economy minus the present discounted value of fuel savings that would accompany such an improvement. To demonstrate robustness across specifications, the results of four hedonic price functions are presented. The series names indicated in the legend correspond to the specification names used in Table 5. The present discounted value of fuel savings is calculated using a 15 percent discount rate. Monthly driving distance is assumed to be 1,870 kilometers for diesel hatchbacks. For any given year, the estimate of the implicit marginal price of fuel economy is the only thing that changes across specifications; the present discounted value of fuel savings is identical across all specifications. 


\section{Figure 7. 95 Percent Confidence Intervals of Fuel Economy Premium Minus Present Discounted Value of Fuel Savings, 2002 to 2006-Petrol Sedan}

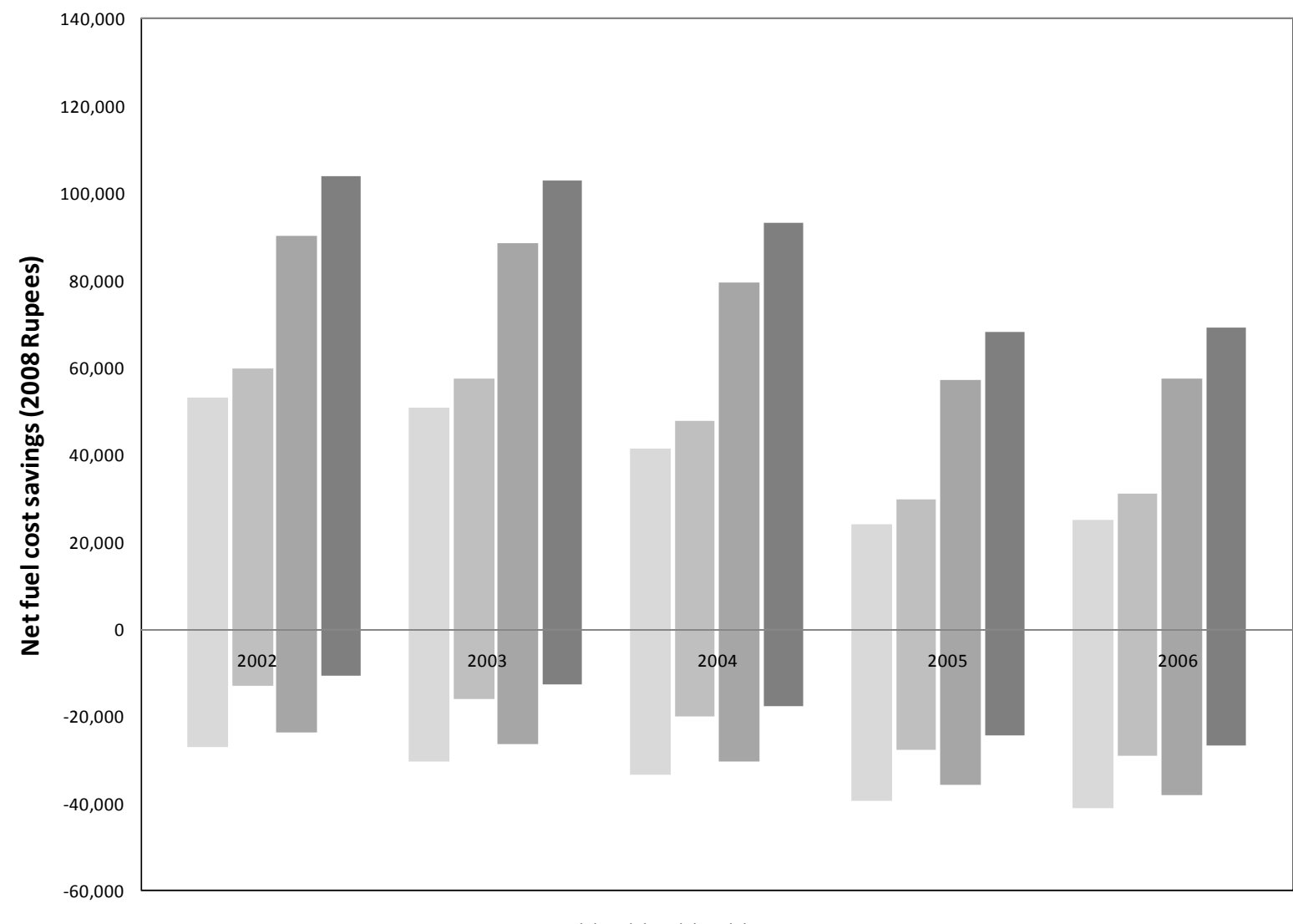

Notes: The above graph presents 95 percent confidence intervals of hedonic price function estimates of the implicit marginal price of a $1 \mathrm{kpl}$ improvement in fuel economy minus the present discounted value of fuel savings that would accompany such an improvement. To demonstrate robustness across specifications, the results of four hedonic price functions are presented. The series names indicated in the legend correspond to the specification names used in Table 6. The present discounted value of fuel savings is calculated using a 15 percent discount rate. Monthly driving distance is assumed to be 1,300 kilometers for petrol sedans. For any given year, the estimate of the implicit marginal price of fuel economy is the only thing that changes across specifications; the present discounted value of fuel savings is identical across all specifications. 


\section{Figure 8. 95 Percent Confidence Intervals of Fuel Economy Premium Minus Present Discounted Value of Fuel Savings, 2002 to 2006-Diesel Sedan}

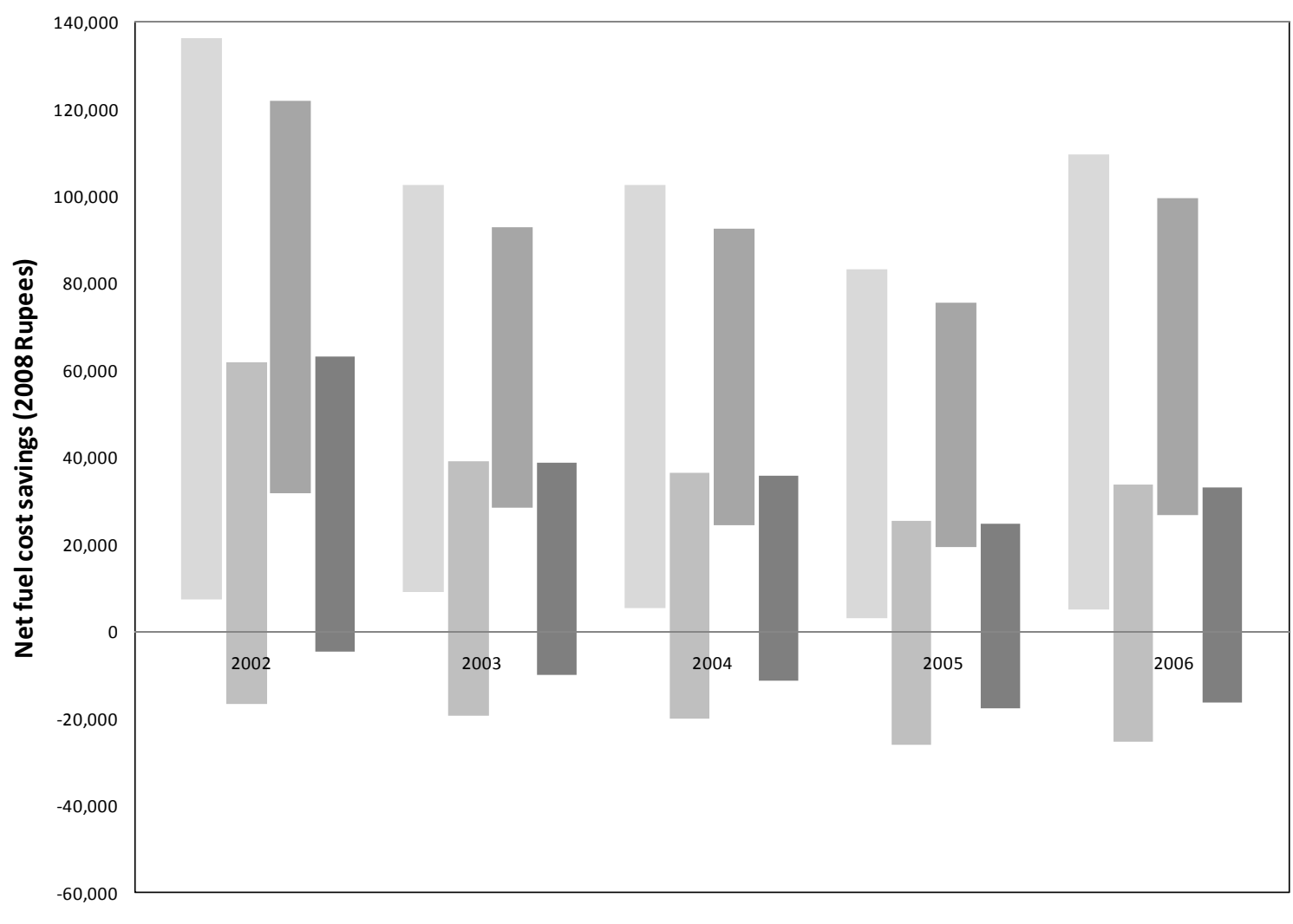

$\square(1) \square(2) \square(3) \square(4)$

Notes: The above graph presents 95 percent confidence intervals of hedonic price function estimates of the implicit marginal price of a $1 \mathrm{kpl}$ improvement in fuel economy minus the present discounted value of fuel savings that would accompany such an improvement. To demonstrate robustness across specifications, the results of four hedonic price functions are presented. The series names indicated in the legend correspond to the specification names used in Table 7. The present discounted value of fuel savings is calculated using a 15 percent discount rate. Monthly driving distance is assumed to be 1,870 kilometers for diesel sedans. For any given year, the estimate of the implicit marginal price of fuel economy is the only thing that changes across specifications; the present discounted value of fuel savings is identical across all specifications. 
Figure 9. Potential Savings as a Percentage of Petrol Twin Purchase Price-Hatchback

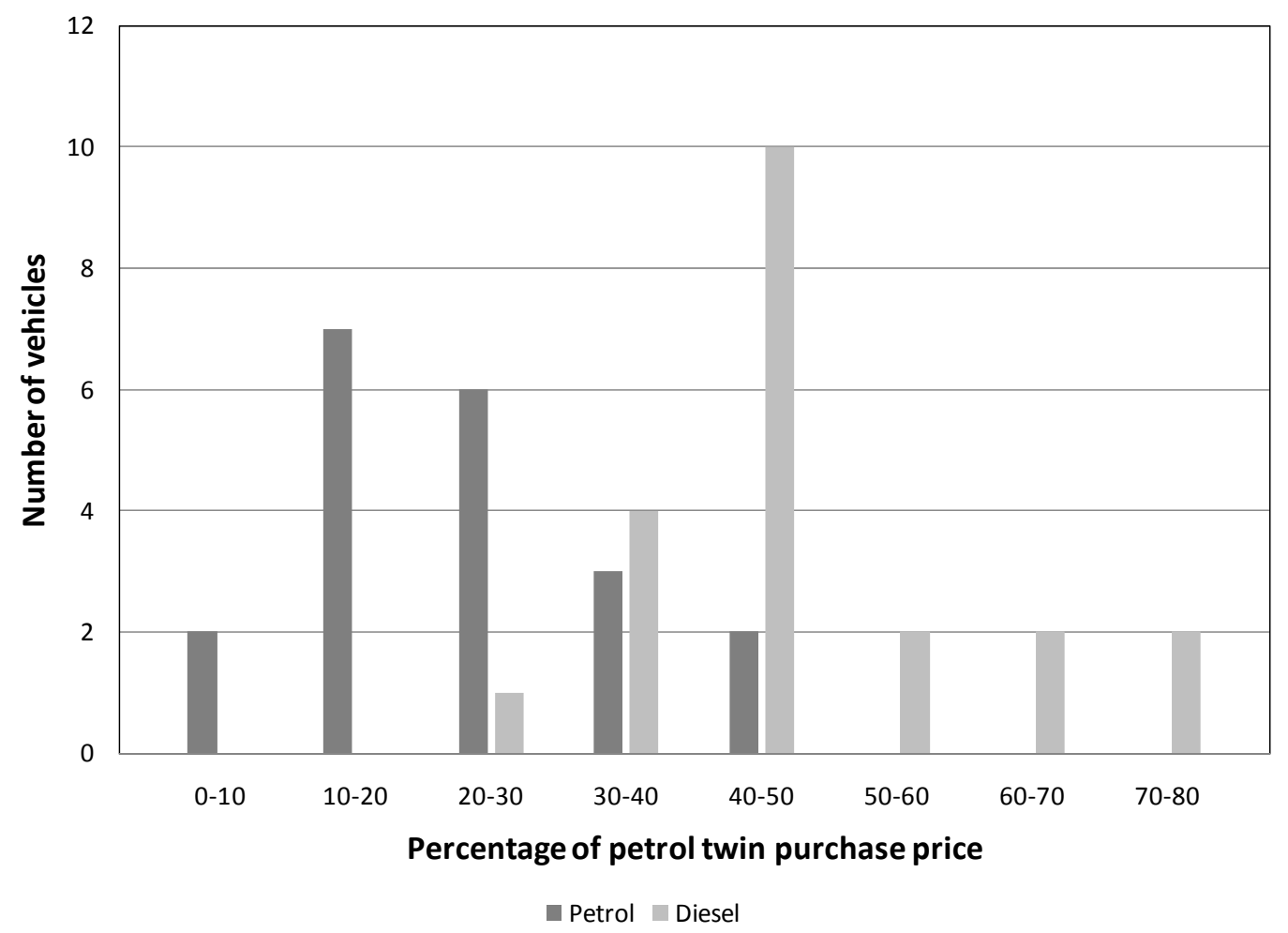

Notes: The above graph presents the frequency distribution of potential savings from buying a diesel hatchback as a percentage of its petrol twin's purchase price. Results for all available twin hatchbacks in years 2002 to 2008 are represented. For owners of petrol hatchbacks, these potential savings are ultimately forgone. For owners of diesel hatchbacks, the potential savings are ultimately realized. Potential savings is calculated as the difference in purchase price between the petrol vehicle and its diesel twin plus the present discounted value of the difference in fuel cost over an 11-year period. In general, this value is positive because, for almost all models available in both fuel types, the diesel twin has a higher purchase price but operating costs low enough to more than offset the purchase price difference. The only difference between the petrol and diesel series is in the monthly driving distance used to calculate the present discounted value of fuel savings. The present discounted value of fuel savings is calculated using a 15 percent discount rate. Monthly driving distance is assumed to be 1,070 kilometers for petrol hatchback owners and 1,870 kilometers for diesel hatchback owners. 


\section{Figure 10. Potential Savings as a Percentage of Petrol Twin Purchase Price-Sedan}

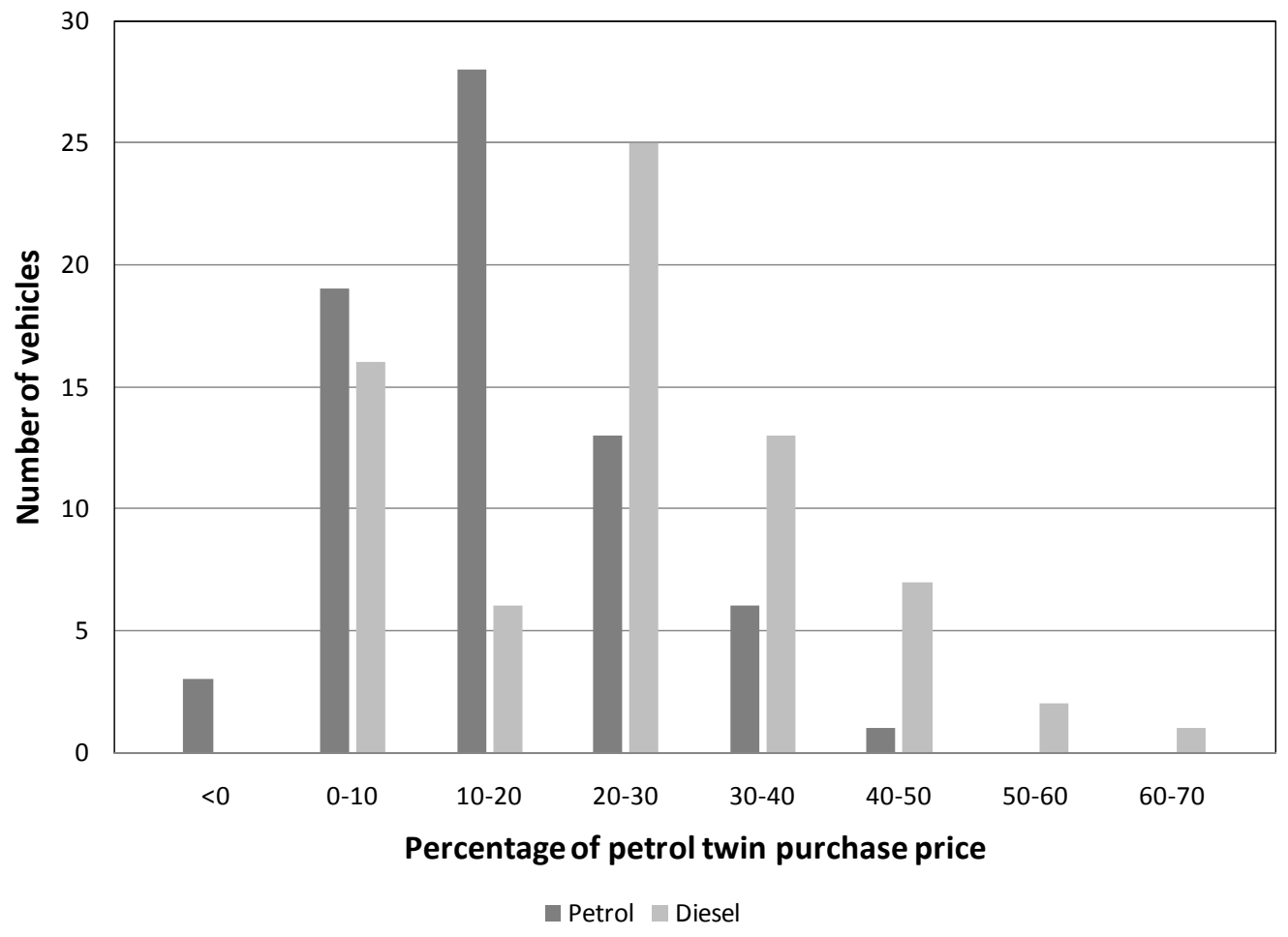

Notes: The above graph presents the frequency distribution of potential savings from buying a diesel sedan as a percentage of its petrol twin's purchase price. Results for all available twin sedans in years 2002 to 2008 are represented. For owners of petrol sedans, these potential savings are ultimately forgone. For owners of diesel sedans, the potential savings are ultimately realized. Potential savings is calculated as the difference in purchase price between the petrol vehicle and its diesel twin plus the present discounted value of the difference in fuel cost over a 12 -year period. In general, this value is positive because, for almost all models available in both fuel types, the diesel twin has a higher purchase price but operating costs low enough to more than offset the purchase price difference. The only difference between the Petrol and Diesel series is in the monthly driving distance used to calculate the present discounted value of fuel savings. The present discounted value of fuel savings is calculated using a 15 percent discount rate. Monthly driving distance is assumed to be 1,300 kilometers for petrol sedan owners and 1,870 kilometers for diesel sedan owners. 


\section{Appendix}

Table A.1. Hedonic Price Function OLS Estimation Results-Petrol Hatchback

\begin{tabular}{|c|c|c|c|c|}
\hline \multirow[b]{3}{*}{ Variables } & \multicolumn{4}{|c|}{ Specifications } \\
\hline & (1) & (2) & (3) & (4) \\
\hline & Logdelhi2008 & Logdelhi2008 & 3 Logdelhi2008 & Logdelhi2008 \\
\hline \multirow[t]{2}{*}{ City fuel economy } & $0.0144 * *$ & 0.000870 & 0.0128 & 0.00381 \\
\hline & $(0.00673)$ & $(0.00739)$ & $(0.00776)$ & $(0.00860)$ \\
\hline \multirow[t]{2}{*}{ Kerb weight } & $0.872 * * *$ & $1.161^{* * *}$ & $0.393 * * *$ & $0.379 * * *$ \\
\hline & $(0.0657)$ & $(0.0977)$ & $(0.100)$ & $(0.0992)$ \\
\hline \multirow[t]{2}{*}{ Power ratio } & $9.905^{* * *}$ & $13.63^{* * *}$ & & \\
\hline & $(0.912)$ & (1.301) & & \\
\hline \multirow[t]{2}{*}{ Engine size } & & $-0.000335^{* * *}$ & & $-0.000325^{* *}$ \\
\hline & & $(8.58 e-05)$ & & $(0.000140)$ \\
\hline \multirow[t]{2}{*}{ Torque } & & & $0.0479 * * *$ & $0.0779 * * *$ \\
\hline & & & $(0.00713)$ & $(0.0147)$ \\
\hline \multirow[t]{2}{*}{ Luxury index } & $0.0724 * * *$ & $0.0709 * * *$ & $0.0833 * * *$ & $0.0834 * * *$ \\
\hline & $(0.00506)$ & $(0.00492)$ & $(0.00547)$ & $(0.00542)$ \\
\hline \multirow[t]{2}{*}{ Safety index } & $-0.0276 * *$ & $-0.0300 * *$ & -0.0179 & -0.0178 \\
\hline & $(0.0123)$ & $(0.0120)$ & $(0.0138)$ & $(0.0136)$ \\
\hline \multirow{2}{*}{ Automatic } & $0.134 * * *$ & $0.129 * * *$ & $0.100 * * *$ & $0.0873^{* *}$ \\
\hline & $(0.0338)$ & $(0.0328)$ & $(0.0377)$ & $(0.0378)$ \\
\hline \multirow[t]{2}{*}{ Y2003 } & $-0.0712 * * *$ & $-0.0799 * * *$ & $-0.0466 *$ & $-0.0479 *$ \\
\hline & $(0.0242)$ & $(0.0236)$ & $(0.0270)$ & $(0.0268)$ \\
\hline \multirow[t]{2}{*}{ Y2004 } & $-0.143^{* * *}$ & $-0.144^{* * *}$ & $-0.129 * * *$ & $-0.126 * * *$ \\
\hline & $(0.0256)$ & $(0.0249)$ & $(0.0288)$ & $(0.0285)$ \\
\hline \multirow[t]{2}{*}{ Y2005 } & $-0.221 * * *$ & $-0.231 * * *$ & $-0.198 * * *$ & $-0.202 * * *$ \\
\hline & $(0.0247)$ & $(0.0241)$ & $(0.0276)$ & $(0.0274)$ \\
\hline \multirow[t]{2}{*}{ Y2006 } & $-0.166 * * *$ & $-0.172 * * *$ & $-0.163 * * *$ & $-0.169 * * *$ \\
\hline & $(0.0247)$ & $(0.0240)$ & (0.0277) & $(0.0276)$ \\
\hline \multirow[t]{2}{*}{ Y2007 } & $-0.277^{* * *}$ & $-0.281 * * *$ & $-0.297 * * *$ & $-0.309 * * *$ \\
\hline & $(0.0254)$ & $(0.0247)$ & $(0.0285)$ & $(0.0287)$ \\
\hline \multirow[t]{2}{*}{ Y2008 } & $-0.302 * * *$ & $-0.312^{* * *}$ & $-0.331 * * *$ & $-0.350 * * *$ \\
\hline & $(0.0243)$ & $(0.0237)$ & $(0.0271)$ & $(0.0281)$ \\
\hline \multirow[t]{2}{*}{ Constant } & -0.208 & -0.198 & $0.477^{* * *}$ & $0.677^{* * *}$ \\
\hline & $(0.145)$ & $(0.141)$ & $(0.137)$ & $(0.161)$ \\
\hline Observations & 244 & 244 & 244 & 244 \\
\hline R-squared & 0.881 & 0.888 & 0.850 & 0.853 \\
\hline
\end{tabular}

Notes: Table presents hedonic price function OLS estimation results using petrol hatchbacks for years 2002 to 2008 . To analyze robustness of results, we present four different specifications. Standard errors are in parentheses, *** $\mathrm{p}<0.01, * * \mathrm{p}<0.05, * \mathrm{p}<0.1$ 


\section{Table A.2. Hedonic Price Function OLS Estimation Results-Diesel Hatchback}

\begin{tabular}{|c|c|c|c|c|}
\hline \multirow[b]{3}{*}{ Variables } & \multicolumn{4}{|c|}{ Specifications } \\
\hline & (1) & (2) & (3) & (4) \\
\hline & Logdelhi2008 & Logdelhi2008 & Logdelhi2008 & Logdelhi2008 \\
\hline \multirow[t]{2}{*}{ City fuel economy } & $0.0358 * * *$ & $0.0363 * * *$ & $0.0281 * *$ & $0.0292 * * *$ \\
\hline & $(0.0107)$ & (0.0103) & $(0.0110)$ & $(0.0104)$ \\
\hline \multirow[t]{2}{*}{ Kerb weight } & $1.109 * * *$ & $0.922 * * *$ & $0.535 * * *$ & $0.385 * * *$ \\
\hline & $(0.137)$ & $(0.161)$ & $(0.136)$ & $(0.140)$ \\
\hline \multirow[t]{2}{*}{ Power ratio } & $7.606 * * *$ & $6.671 * * *$ & & \\
\hline & (1.133) & $(1.187)$ & & \\
\hline \multirow[t]{2}{*}{ Engine size } & & $0.000119 * *$ & & $0.000145^{* *}$ \\
\hline & & $(5.74 e-05)$ & & $(5.42 e-05)$ \\
\hline \multirow[t]{2}{*}{ Torque } & & & $0.0251 * * *$ & $0.0221 * * *$ \\
\hline & & & $(0.00374)$ & $(0.00370)$ \\
\hline \multirow[t]{2}{*}{ Luxury index } & $0.0427 * * *$ & $0.0451^{* * *}$ & $0.0432 * * *$ & $0.0458 * * *$ \\
\hline & $(0.00657)$ & $(0.00648)$ & $(0.00655)$ & $(0.00627)$ \\
\hline \multirow[t]{2}{*}{ Safety index } & 0.00889 & -0.000693 & 0.00796 & -0.00373 \\
\hline & $(0.0136)$ & $(0.0140)$ & $(0.0136)$ & $(0.0136)$ \\
\hline \multirow[t]{2}{*}{ Automatic } & 0 & 0 & 0 & 0 \\
\hline & (0) & (0) & (0) & (0) \\
\hline \multirow[t]{2}{*}{ Y2003 } & $-0.0691 * *$ & $-0.0801^{* * *}$ & $-0.0735 * *$ & $-0.0869 * * *$ \\
\hline & $(0.0288)$ & $(0.0284)$ & $(0.0289)$ & $(0.0278)$ \\
\hline \multirow[t]{2}{*}{ Y2004 } & $-0.151 * * *$ & $-0.152 * * *$ & $-0.147 * * *$ & $-0.148 * * *$ \\
\hline & $(0.0290)$ & $(0.0281)$ & $(0.0290)$ & $(0.0274)$ \\
\hline \multirow[t]{2}{*}{ Y2005 } & $-0.140 * * *$ & $-0.134 * * *$ & $-0.144 * * *$ & $-0.137 * * *$ \\
\hline & $(0.0340)$ & $(0.0330)$ & $(0.0340)$ & $(0.0323)$ \\
\hline \multirow[t]{2}{*}{ Y2006 } & -0.0590 & -0.0417 & $-0.0667^{*}$ & -0.0449 \\
\hline & $(0.0364)$ & $(0.0362)$ & $(0.0364)$ & $(0.0354)$ \\
\hline \multirow[t]{2}{*}{ Y2007 } & $-0.202 * * *$ & $-0.179 * * *$ & $-0.210 * * *$ & $-0.182 * * *$ \\
\hline & $(0.0338)$ & $(0.0346)$ & $(0.0340)$ & $(0.0338)$ \\
\hline \multirow[t]{2}{*}{ Y2008 } & $-0.288 * * *$ & $-0.241 * * *$ & $-0.310 * * *$ & $-0.254 * * *$ \\
\hline & (0.0359) & (0.0414) & $(0.0373)$ & $(0.0411)$ \\
\hline \multirow[t]{2}{*}{ Constant } & $-0.441^{*}$ & $-0.403^{*}$ & $0.421 *$ & 0.350 \\
\hline & $(0.240)$ & $(0.234)$ & $(0.235)$ & $(0.224)$ \\
\hline Observations & 64 & 64 & 64 & 64 \\
\hline R-squared & 0.880 & 0.889 & 0.879 & 0.894 \\
\hline
\end{tabular}

Notes: Table presents hedonic price function OLS estimation results using diesel hatchbacks for years 2002 to 2008. To analyze robustness of results, we present four different specifications. Standard errors are in parentheses, *** $\mathrm{p}<0.01,{ }^{* *} \mathrm{p}<0.05,{ }^{*} \mathrm{p}<0.1$ 
Table A.3. Hedonic Price Function OLS Estimation Results-Petrol Sedan

\begin{tabular}{|c|c|c|c|c|}
\hline \multirow[b]{3}{*}{ Variables } & \multicolumn{4}{|c|}{ Specifications } \\
\hline & (1) & (2) & (3) & (4) \\
\hline & Logdelhi2008 & Logdelhi2008 & Logdelhi2008 & 3 Logdelhi2008 \\
\hline \multirow[t]{2}{*}{ City fuel economy } & $0.0472^{* * *}$ & $0.0442^{* * *}$ & $0.0264^{* *}$ & $0.0260^{* *}$ \\
\hline & $(0.0114)$ & $(0.0114)$ & $(0.0107)$ & $(0.0106)$ \\
\hline \multirow[t]{2}{*}{ Kerb weight } & $1.865^{* * *}$ & $1.633^{* * *}$ & $0.815^{* * *}$ & $0.842^{* * *}$ \\
\hline & (0.0899) & $(0.126)$ & $(0.112)$ & $(0.112)$ \\
\hline \multirow[t]{2}{*}{ Power ratio } & $8.987^{* * *}$ & $7.404^{* * *}$ & & \\
\hline & $(0.679)$ & $(0.899)$ & & \\
\hline \multirow[t]{2}{*}{ Engine size } & & $0.000107^{* * *}$ & & $-0.000140 * * *$ \\
\hline & & $(4.04 e-05)$ & & $(5.25 e-05)$ \\
\hline \multirow[t]{2}{*}{ Torque } & & & $0.0506^{* * *}$ & $0.0639 * * *$ \\
\hline & & & (0.00334) & (0.00599) \\
\hline \multirow[t]{2}{*}{ Luxury index } & $0.0579 * * *$ & $0.0605^{* * *}$ & $0.0668 * * *$ & $0.0652^{* * *}$ \\
\hline & $(0.00566)$ & $(0.00572)$ & $(0.00535)$ & $(0.00534)$ \\
\hline \multirow[t]{2}{*}{ Safety index } & -0.0188 & -0.0108 & 0.00942 & 0.00571 \\
\hline & $(0.0127)$ & $(0.0130)$ & $(0.0120)$ & $(0.0120)$ \\
\hline \multirow{2}{*}{ Automatic } & $0.179 * * *$ & $0.181 * * *$ & $0.174 * * *$ & $0.168^{* * *}$ \\
\hline & $(0.0301)$ & $(0.0300)$ & $(0.0288)$ & $(0.0287)$ \\
\hline \multirow[t]{2}{*}{ Y2003 } & 0.00226 & 0.00733 & 0.0110 & 0.00635 \\
\hline & $(0.0367)$ & $(0.0365)$ & $(0.0350)$ & $(0.0348)$ \\
\hline \multirow[t]{2}{*}{ Y2004 } & $-0.121 * * *$ & $-0.122^{* * *}$ & $-0.126^{* * *}$ & $-0.126^{* * *}$ \\
\hline & $(0.0355)$ & $(0.0352)$ & $(0.0339)$ & $(0.0336)$ \\
\hline \multirow[t]{2}{*}{ Y2005 } & $-0.198 * * *$ & $-0.197 * * *$ & $-0.213 * * *$ & $-0.217^{* * *}$ \\
\hline & $(0.0377)$ & $(0.0376)$ & $(0.0362)$ & $(0.0360)$ \\
\hline \multirow[t]{2}{*}{ Y2006 } & $-0.212^{* * *}$ & $-0.212^{* * *}$ & $-0.245^{* * *}$ & $-0.254^{* * *}$ \\
\hline & $(0.0356)$ & $(0.0353)$ & $(0.0340)$ & (0.0339) \\
\hline \multirow[t]{2}{*}{ Y2007 } & $-0.279 * * *$ & $-0.272 * * *$ & $-0.301 * * *$ & $-0.316^{* * *}$ \\
\hline & $(0.0355)$ & $(0.0354)$ & $(0.0340)$ & $(0.0342)$ \\
\hline \multirow[t]{2}{*}{ Y2008 } & $-0.352^{* * *}$ & $-0.348^{* * *}$ & $-0.375^{* * *}$ & $-0.387^{* * *}$ \\
\hline & $(0.0366)$ & $(0.0364)$ & $(0.0351)$ & $(0.0351)$ \\
\hline \multirow[t]{2}{*}{ Constant } & $-1.254^{* * *}$ & $-1.027^{* * *}$ & 0.124 & 0.156 \\
\hline & $(0.190)$ & $(0.207)$ & $(0.171)$ & $(0.170)$ \\
\hline Observations & 412 & 411 & 411 & 411 \\
\hline R-squared & 0.919 & 0.921 & 0.927 & 0.928 \\
\hline
\end{tabular}

Notes: Table presents hedonic price function OLS estimation results using petrol sedans for years 2002 to 2008 . To analyze robustness of results, we present four different specifications. Standard errors are in parentheses, *** $\mathrm{p}<0.01, * * \mathrm{p}<0.05,{ }^{*} \mathrm{p}<0.1$ 
Table A.4. Hedonic Price Function OLS Estimation Results-Diesel Sedan

\begin{tabular}{|c|c|c|c|c|}
\hline \multirow[b]{3}{*}{ Variables } & \multicolumn{4}{|c|}{ Specifications } \\
\hline & (1) & $(2)$ & (3) & (4) \\
\hline & Logdelhi2008 & Logdelhi2008 & Logdelhi2008 & 3 Logdelhi2008 \\
\hline \multirow[t]{2}{*}{ City fuel economy } & 0.0137 & $0.0273 * * *$ & 0.00866 & $0.0239 * *$ \\
\hline & $(0.0103)$ & (0.00983) & $(0.0112)$ & (0.0107) \\
\hline \multirow[t]{2}{*}{ Kerb weight } & $1.194 * * *$ & $0.858^{* * *}$ & $0.673^{* *}$ & 0.375 \\
\hline & $(0.203)$ & (0.198) & $(0.271)$ & $(0.255)$ \\
\hline \multirow[t]{2}{*}{ Power ratio } & $7.700^{* * *}$ & $6.884 * * *$ & & \\
\hline & $(1.138)$ & $(1.059)$ & & \\
\hline \multirow[t]{2}{*}{ Engine size } & & $0.000289 * * *$ & & $0.000310 * * *$ \\
\hline & & $(5.55 e-05)$ & & $(5.85 e-05)$ \\
\hline \multirow[t]{2}{*}{ Torque } & & & $0.0206 * * *$ & $0.0182^{* * *}$ \\
\hline & & & $(0.00415)$ & (0.00384) \\
\hline \multirow[t]{2}{*}{ Luxury index } & $0.0974 * * *$ & $0.0839 * * *$ & $0.102^{* * *}$ & $0.0874 * * *$ \\
\hline & $(0.00800)$ & $(0.00780)$ & $(0.00840)$ & $(0.00821)$ \\
\hline \multirow[t]{2}{*}{ Safety index } & -0.0194 & 0.00858 & -0.0135 & 0.0158 \\
\hline & $(0.0216)$ & $(0.0206)$ & $(0.0229)$ & $(0.0217)$ \\
\hline \multirow[t]{2}{*}{ Automatic } & $0.320 * * *$ & $0.318^{* * *}$ & $0.340 * * *$ & $0.336 * * *$ \\
\hline & $(0.0487)$ & $(0.0448)$ & $(0.0514)$ & $(0.0472)$ \\
\hline \multirow[t]{2}{*}{ Y2003 } & 0.0496 & 0.0605 & 0.0826 & $0.0907^{*}$ \\
\hline & $(0.0506)$ & $(0.0466)$ & $(0.0531)$ & $(0.0487)$ \\
\hline \multirow[t]{2}{*}{ Y2004 } & 0.000737 & -0.00652 & 0.0195 & 0.00980 \\
\hline & $(0.0513)$ & $(0.0472)$ & $(0.0544)$ & $(0.0500)$ \\
\hline \multirow[t]{2}{*}{ Y2005 } & $-0.135 * * *$ & $-0.135 * * *$ & $-0.117^{* *}$ & $-0.119 * *$ \\
\hline & $(0.0512)$ & $(0.0472)$ & $(0.0546)$ & $(0.0502)$ \\
\hline \multirow[t]{2}{*}{ Y2006 } & $-0.168 * * *$ & $-0.165^{* * *}$ & $-0.144 * * *$ & $-0.144 * * *$ \\
\hline & $(0.0521)$ & $(0.0480)$ & $(0.0552)$ & $(0.0506)$ \\
\hline \multirow[t]{2}{*}{ Y2007 } & $-0.239 * * *$ & $-0.211^{* * *}$ & $-0.230 * * *$ & $-0.201^{* * *}$ \\
\hline & $(0.0506)$ & $(0.0469)$ & $(0.0543)$ & $(0.0502)$ \\
\hline \multirow[t]{2}{*}{ Y2008 } & $-0.324 * * *$ & $-0.300 * * *$ & $-0.317^{* * *}$ & $-0.292 * * *$ \\
\hline & $(0.0507)$ & $(0.0469)$ & $(0.0550)$ & $(0.0507)$ \\
\hline \multirow[t]{2}{*}{ Constant } & -0.158 & -0.355 & $0.615^{*}$ & 0.314 \\
\hline & $(0.301)$ & $(0.279)$ & (0.369) & $(0.343)$ \\
\hline Observations & 158 & 158 & 158 & 158 \\
\hline R-squared & 0.936 & 0.946 & 0.928 & 0.939 \\
\hline
\end{tabular}

Notes: Table presents hedonic price function OLS estimation results using petrol sedans for years 2002 to 2008 . To analyze robustness of results, we present four different specifications. Standard errors are in parentheses, ${ }^{* * *}$ $\mathrm{p}<0.01, * * \mathrm{p}<0.05, * \mathrm{p}<0.1$ 
Table A.5. City Fuel Economy Coefficients with and without Squared Terms

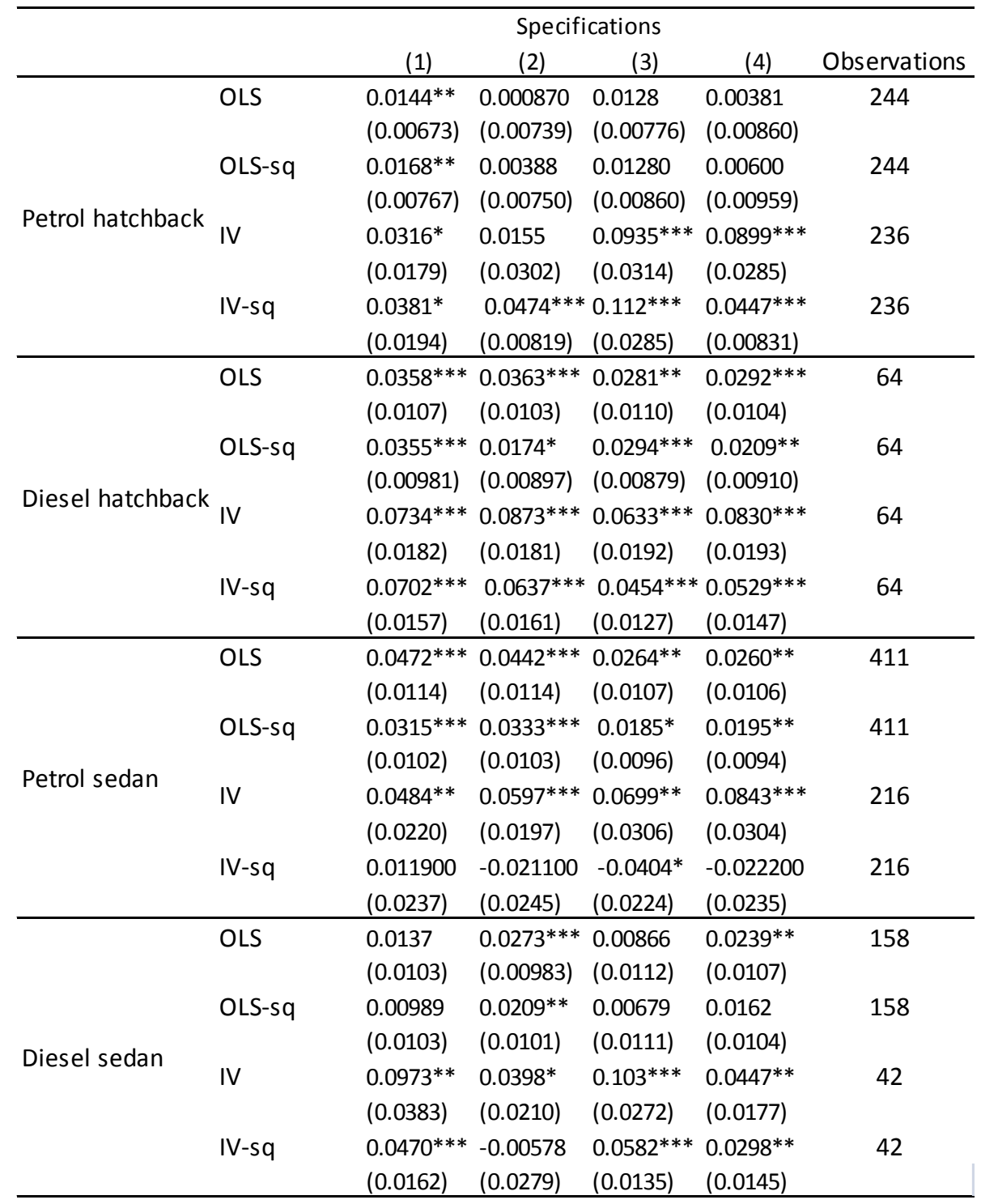

Notes: This table presents OLS and IV hedonic price function city fuel economy coefficient estimates. OLS-sq and IV-sq refer to OLS and IV specifications which include squared continuous variables. In these cases the first stage includes the square of the instrumental variable. Standard errors in parentheses, ${ }^{* * *} \mathrm{p}<0.01, * * \mathrm{p}<0.05,{ }^{*} \mathrm{p}<0.1$ 